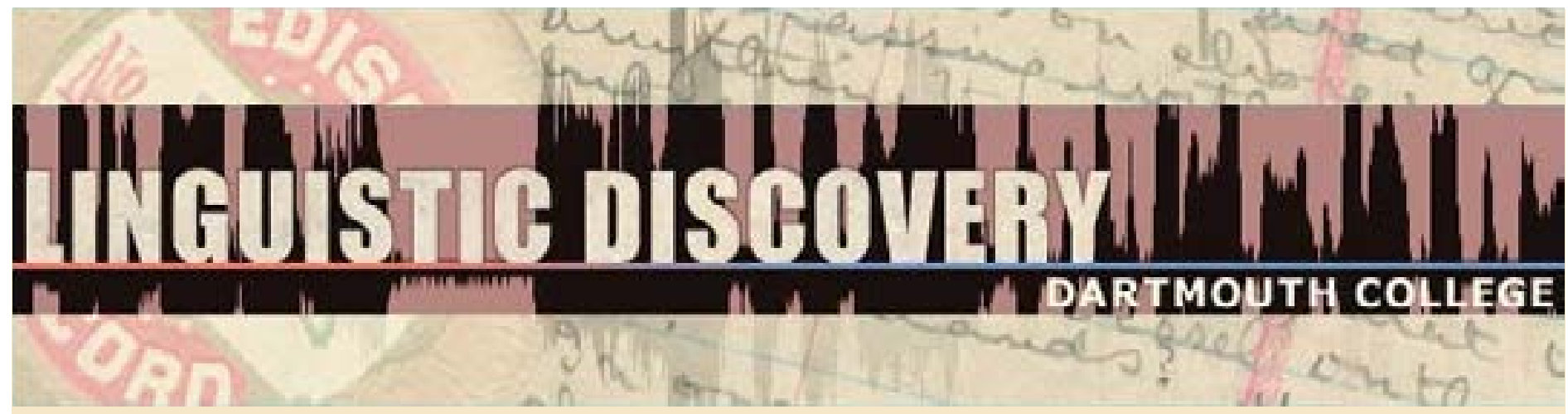

\begin{tabular}{|l|}
\hline Volume 5 \\
Issue 1 \\
2007
\end{tabular}

\title{
Lexicon and Description of Sui Adjective
} Intensifiers

James N. Stanford

Michigan State University

doi: $10.1349 / P S 1.1537-0852 . A .313$

url: http://journals.dartmouth.edu/cgi-bin/WebObjects/ Journals.woa/1/xmlpage/1/article/313

\section{Linguistic Discovery}

Published by the Dartmouth College Library Copyright to this article is held by the authors. ISSN 1537-0852 linguistic-discovery.dartmouth.edu 


\title{
Lexicon and Description of Sui Adjective Intensifiers
}

\author{
James N. Stanford \\ Michigan State University
}

Sui, an indigenous minority language of southwest China, has an elaborate system of adjective intensification. Adjectives are intensified with word-specific, bound morphemes that usually either rhyme with the base or alliterate with the base. Stanford (2007) notes morphophonological patterns that suggest reduplication, rhyme, alliteration, The Emergence of the Unmarked (McCarthy \& Prince 1994, Yip 2001), identity avoidance, and "Copy But Don't Repeat" (Kennard 2004). However, the adjective intensifiers defy a simple, fully predictable explanation in such terms; the intensifier lexicon may be best described as "patterned variety," a case of lexicalized poetry or a poeticized lexicon. Word formation is guided by general patterns, but each specific intensifier may vary within those overall guidelines. Many adjectives have multiple intensifiers that bear subtle semantic and pragmatic distinctions. The current paper serves as a complement to Stanford (2007) by providing a detailed lexicon of the Sui adjective intensifiers for future reference and further analysis. This lexicon is based on the author's fieldwork and represents the first detailed account of Sui adjective intensifiers for the wider linguistic community.

\section{Introduction ${ }^{1}$}

The Sui people are an indigenous ethnic minority of southwest Chin, numbering 346,000 in a 1990 census (He et al. 1992:1) and reported to be 406,902 in 2000 (Xuecun Wei, Chinese Academy of Social Sciences). The great majority (93\%) live in southern Guizhou Province (Burusphat et al. 2003). The language, a member of the Tai-Kadai family, is isolating, tonal, and largely monosyllabic.

\subsection{Sui Phonology}

Sui consonants are given below following Li (1948), Shuiyu Diaocha Baogao ${ }^{2}$ (1956), Zhang (1980), Luo (1992), Zeng \& Yao (1996), Edmondson et al. (2004), as well as the author's observations of the specific village under investigation, Ljaj $\mathrm{Ku}$ Tsong (Zhonghe Township, Sandu Autonomous Sui County).

\footnotetext{
${ }^{1}$ I would like to thank Yen-Hwei Lin for her extensive advice on this project, the Sui people who patiently taught me to speak their language and kindly allowed me to elicit this set of data, Jerold Edmondson, Tim and Debbie Vinzani, Grover Hudson, Dennis Preston, David Dwyer, the editors and reviewers of Journal of East Asian Linguistics, the audience at the Third Workshop on Theoretical East Asian Linguistics, and Qiannan Minority Teacher College.

${ }^{2}$ Shuiyu Diaocha Baogao [Report on Investigations of the Sui language] is an unpublished manuscript from 1956. A copy of the manuscript was acquired through the help of Jerold Edmondson.
} 


\begin{tabular}{|c|c|c|c|c|c|}
\hline $\mathrm{p}$ & $\mathrm{t}$ & ts & t6 & $\mathrm{k}$ & $q$ \\
\hline $\mathrm{p}^{\mathrm{h}}$ & $\mathrm{t}^{\mathrm{h}}$ & $\mathrm{ts}^{\mathrm{h}}$ & $\mathrm{t}^{\mathrm{h}}$ & $\mathrm{k}^{\mathrm{h}}$ & $\mathrm{q}^{\mathrm{h}}$ \\
\hline${ }^{\mathrm{m}} \mathrm{b}$ & ${ }^{\mathrm{n}} \mathrm{d}$ & & & & \\
\hline $\mathrm{Pb}$ & $\mathrm{Pd}$ & & & & \\
\hline $\mathrm{m}_{\circ}$ & no & & $\mathrm{n}_{0}$ & y & \\
\hline $\mathrm{m}$ & $\mathrm{n}$ & & $\mathrm{n}$ & $\mathrm{y}$ & \\
\hline ?m & ?n & & ?n & ?y & \\
\hline $\mathrm{f}$ & $\mathrm{s}$ & & 6 & $x$ & \\
\hline $\mathrm{w}$ & $\mathrm{Z}$ & & & $\begin{array}{l}\text { y } \\
\text { ?y }\end{array}$ & Б \\
\hline & 1 & & $\mathrm{j}$ & & \\
\hline ?w & & & $\begin{array}{l}\mathrm{ij} \\
\text { Consc }\end{array}$ & & \\
\hline
\end{tabular}

Table 2 outlines the Sui tone inventory of Ljaj Ku Tsong Village. The inventory is based on the author's observations and comparison with Shuiyu Diaocha Baogao (1956), Zhang (1980), Luo (1992), Zeng \& Yao (1996). The table follows Chao's (1930) 1-5 scale for contour tones (1=low, $5=$ high). Tone numbers are based on the traditional system used for areal languages (e.g. Li 1948, Zhang 1980, Edmondson \& Solnit 1988). The even/odd distinction in tone numbers represents an interpretation of a historical tone split; even-numbered tones indicate syllables that are supposed to have had historically voiced onsets, while odd-numbered tones indicate syllables with historically voiceless onsets (Li 1948, Edmondson \& Solnit 1988). Tones 7 and 8 represent "checked" syllables (defined in this transcription system as syllables ending in $-p$, $-t$, or $-k$ ). Finally, checked syllables are distinguished as S (short vowel) and L (long vowel). ${ }^{4}$

\begin{tabular}{|c|c|c|c|c|c|c|c|c|c|}
\hline $\begin{array}{l}\text { Tone } \\
1\end{array}$ & $\begin{array}{l}\text { Tone } \\
2\end{array}$ & $\begin{array}{l}\text { Tone } \\
3\end{array}$ & $\begin{array}{l}\text { Tone } \\
4\end{array}$ & $\begin{array}{l}\text { Tone } \\
5\end{array}$ & $\begin{array}{l}\text { Tone } \\
6\end{array}$ & $\begin{array}{l}\text { Tone } \\
7 \mathrm{~S}\end{array}$ & $\begin{array}{l}\text { Tone } \\
7 \mathrm{~L}\end{array}$ & $\begin{array}{l}\text { Tone } \\
8 \mathrm{~S}\end{array}$ & $\begin{array}{l}\text { Tone } \\
8 \mathrm{~L}\end{array}$ \\
\hline 13 & 31 & 33 & 53 & 35 & 24 & 55 & 35 & 32 & 31 \\
\hline
\end{tabular}

Table 2. Sui tones in Ljaj Ku Tsong village

\footnotetext{
${ }^{3}$ In the region under investigation, the sound represented by $/ \mathrm{w} /$ is usually perceived as having a labio-dental place of articulation when it occurs in syllable-initial position. It may be that it is a labio-dental approximant (cf. Edmondson et al. 2004). The underlying form is not yet entirely clear, so the sound is transcribed [v] in syllableinitial position in this study.

${ }^{4}$ Future study may reveal that the checked tones could be combined with corresponding unchecked tones into an underlying system of just six tones. Li (1948) opts to use all eight tones for clarity, and this transcription system is adopted here.
} 


\subsection{Sui Adjective Intensifiers}

Sui has an elaborate system of adjective intensification that involves rhyme and alliteration. First, note that a generic, non-word-specific intensifier can be used to intensify adjectives, as exemplified in (1).

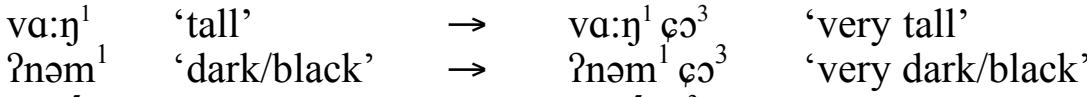

$$
\begin{aligned}
& \text { 'оо }^{5} \quad \text { 'young' } \quad \rightarrow \quad \text { 'ор }^{5} \varphi^{3} \quad \text { 'very young' }
\end{aligned}
$$

However, intensifiers also commonly take the form of a word-specific, bound intensifier. Such intensifiers may be divided into two major classes that Stanford (2007) calls the Rhyming Class and the Alliterative Class. Examples of the Rhyming Class are given in (2).
a. $\quad$ ва: $t^{7} \quad$ 'agile'

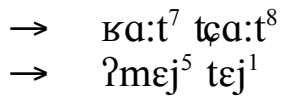
'very agile'
b. $2 m \varepsilon j^{5} \quad$ 'selfish'
'very selfish' (often
c. fa: $\mathrm{y}^{3}$ 'wide'
$\rightarrow \quad f a: \eta^{3} 1^{\mathrm{j} a}: \eta^{2}$
referring to a child)
d. tom ${ }^{1}$ 'dull'
$\rightarrow$ tom $^{1}$ Pnom $^{1}$
'very wide'
e. ${ }^{\mathrm{m}} \mathrm{bu}^{3}$
'bulging'
$\rightarrow \quad \mathrm{mbu}^{3} \mathrm{tc}_{6}^{\mathrm{h}} \mathrm{u}^{5}$
f. 2 nəm ${ }^{1}$ 'dark/black' $\rightarrow$ nnəm $^{1}$ fəm $^{2}$
'very dull'
'very bulging'
g. $\quad$ lap
'garrulous'
$\rightarrow \quad \operatorname{lap}^{7} \operatorname{tap}^{8}$
'very dark/black'
h. $\mathrm{p}^{\mathrm{j}} \varepsilon: \mathrm{k}^{7}$ 'dirty'
$\rightarrow \quad \mathrm{p}^{\mathrm{j}} \varepsilon: \mathrm{k}^{7} \mathrm{l}^{\mathrm{j}} \varepsilon: \mathrm{k}^{7}$
'very garrulous'
i. mow $^{1}$
'crude, rash'
$\rightarrow$ mow $^{1}$ low $^{1}$
'very dirty'
j. ${ }^{\mathrm{m}} \mathrm{b}^{\mathrm{j}} \mathrm{a}^{3} \quad$ 'blurry'
$\rightarrow \quad{ }^{\mathrm{m}} \mathrm{b}^{\mathrm{j}} \mathrm{a}^{3} \mathrm{tc}^{4} \mathrm{a}^{4}$
'very crude/rash'
'very blurry'

Examples of the Alliterative Class are given in (3).
a. $\quad$ ва: $\mathrm{t}^{7}$ 'agile' $\rightarrow$ ва: $\mathrm{t}^{7}$ вош ${ }^{1}$
'very agile'
b. $\quad 2 m \varepsilon j^{5}$ 'selfish' $\rightarrow \quad \mathrm{mej}^{5} \mathrm{Pmu}: \mathrm{t}^{7}$
'very selfish' (general usage)
d. $6 \mathrm{u}^{1} \quad$ 'green' $\rightarrow \mathrm{cu}^{1} \operatorname{cin}^{5}$
'very green'
e. t6 $^{\mathrm{h}} \mathrm{O \eta}^{5} \quad$ 'spicy' $\rightarrow \mathrm{tc}_{6}^{\mathrm{h}} \mathrm{o \eta}^{5} \mathrm{tc}^{\mathrm{h}} \mathrm{at}^{7}$
'very spicy'
f. $\mathrm{za}^{3}$ 'light' $\rightarrow \mathrm{za}^{3} \mathrm{zu}^{1}$
g. $\mathrm{za}^{3} \quad$ 'light' $\rightarrow \mathrm{za}^{3} \mathrm{ze \eta}^{3}$
h. qəm $^{1}$
'bitter' $\rightarrow$ qom $^{1} \mathrm{qe}^{5}$
'sharp' $\rightarrow \quad \mathrm{ca}^{1} \mathrm{\varphi \varepsilon n}^{1}$
'very light/casual' (attitude)
'very light' (weight)
i. $\quad a^{1}$
'muddled'
Бәт ${ }^{1}$ вој ${ }^{1}$
'very bitter'
'very sharp'
'very muddled'

In most cases, the intensifiers are word-specific, bound morphemes which are not attested elsewhere in the language. Homonymy with other lexical items outside the adjective intensifier lexicon occasionally occurs, but Sui speakers consider such rare homonyms to be coincidental and unrelated.

In addition to the two major classes of rhyming and alliterative intensifiers, some intensifiers do not show any phonological resemblance with their bases. For example, xom ${ }^{3}$ 'sour' $\rightarrow$ xom $^{3}$

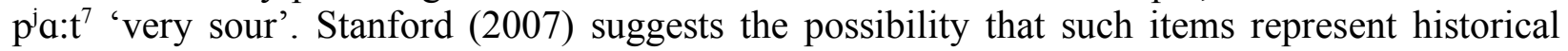
compounds where the second syllable has lost its original status as a stand-alone word. 
Comparing (2a-b) and (3a-b) above, note that a given base adjective may have more than one intensifier. Subtle semantic and pragmatic differences are often observed in such instances. Another example is given in (4).

$$
\begin{aligned}
& \operatorname{tcoy}^{3} \quad \text { 'thin/skinny' } \rightarrow \operatorname{tcoj}^{3} \text { tcen }{ }^{1} \quad \text { 'very thin/skinny' (most common/general) } \\
& \rightarrow \text { tcon }^{3} \text { tcop }{ }^{7} \quad \text { 'very thin/skinny' (derogatory, higher }
\end{aligned}
$$

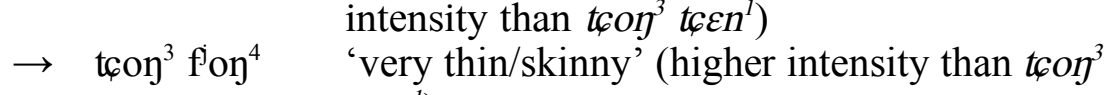

$$
\begin{aligned}
& \left.t_{6 \varepsilon n}{ }^{l}\right)
\end{aligned}
$$

Finally, within the Rhyming Class, there is a subset of complex rhyming expressions involving three or more rhyming syllables. For example:

$$
\begin{aligned}
& \text { t’่ว 'full' } \\
& \text { t’่ว n'ว } \\
& t^{\mathrm{j} \partial \eta} n^{\mathrm{j} \partial \eta} \mathrm{s}^{\mathrm{j} \partial \eta} \text { 'extremely full' }
\end{aligned}
$$

\section{Analysis}

A summary of Stanford's (2007) analysis is given in $§ 2$.

\subsection{The rhyming class}

In the Rhyming Class of intensifiers (e.g. (2)), Stanford (2007) finds clear evidence of The Emergence of the Unmarked (McCarthy \& Prince 1994), the process whereby unmarked forms "emerge" in environments such as reduplication where base-reduplicant identity is ranked lower than markedness constraints (in the Optimality Theoretic terms of Prince \& Smolensky (1993).) Stanford follows Yip's (2001) analysis of reduplication in Chaoyang and other Chinese languages, finding that coronal onsets (i.e., unmarked onsets) are generally favored in the Sui intensifiers. Examples are given in (6).

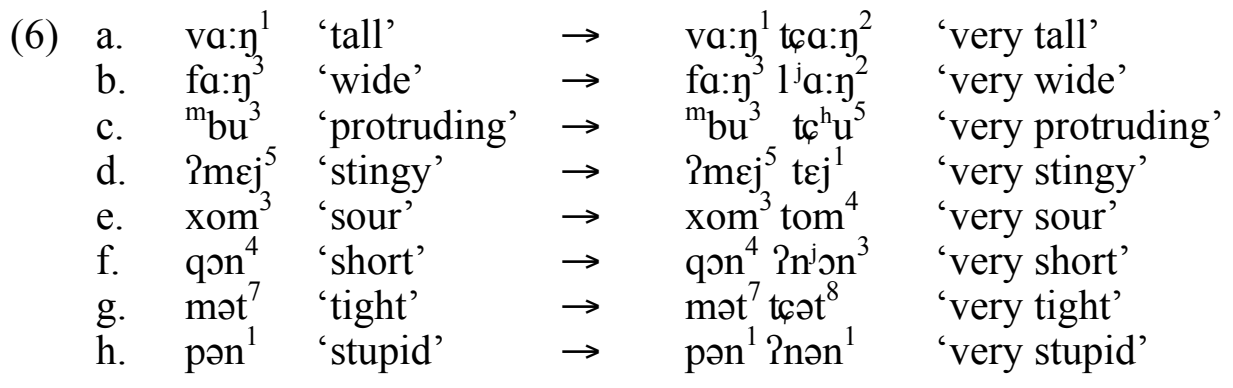

Stanford reports that the intensifier has a coronal onset in $95 \%(56 / 59)$ of the cases where the base onset is non-coronal (as in (6)). For both coronal and non-coronal onset bases, the intensifier has a coronal onset in $88 \%(88 / 100)$ of the cases.

However, Stanford notes that identity avoidance also plays a role in the choice of intensifier

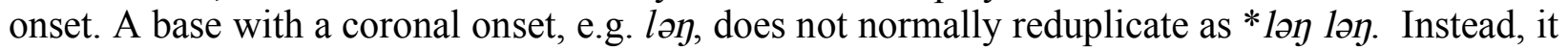
reduplicates as lon ton; i.e., the intensifier remains coronal (following TETU), but the manner of articulation has changed. This suggests the presence of identity avoidance working in conjunction with TETU. Specifically, Stanford follows Yip's (1995a) use of *REPEAT 
(Identical syllables cannot be adjacent) and Kennard's (2004) “Copy But Don't Repeat." In this way, a combination of TETU and identity avoidance is used to explain $l \supset \eta \longrightarrow l \supset \eta$ to $\eta$ and $l \supset \eta \longrightarrow$

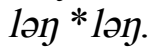

As for tone, Stanford observes that rhyming intensifiers often copy the tone of their bases, although there are some cases where a non-falling-tone base has a falling-tone intensifier.

\subsection{The alliterative class}

Intensifiers in the Alliterative Class (e.g. (3)) do not show evidence of the TETU effects found in the Rhyming Intensifiers. The rhymes of alliterative intensifiers show a great deal of variety. Further, there is no apparent preference for unmarked forms as would be expected of TETU. Identity avoidance is clearly present since the intensifier rhymes differ from their base rhymes, yet the specific choice of rhyme appears to be quite flexible.

\subsection{Patterned variety}

Stanford concludes that Sui intensifiers represent a system of patterned variety that could be described as lexicalized poetry or as a poeticized lexicon. First, note in (7-8) that the presence of multiple intensifier options precludes the possibility of strict word formation rules for a given base.

(7) $\mathrm{p}^{\mathrm{h}} \mathrm{a}^{1}$ :

$$
\begin{aligned}
& \mathrm{p}^{\mathrm{h}} \mathrm{a}^{1} \quad \text { 'gray' } \rightarrow \quad \mathrm{p}^{\mathrm{h}} \mathrm{a}^{1} \mathrm{p}^{\mathrm{h}} \mathrm{oj}{ }^{1} \quad \text { 'very gray' (e.g. ash spots on clothing) } \\
& \mathrm{p}^{\mathrm{h}} \mathrm{a}^{1} \quad \text { 'gray' } \rightarrow \mathrm{p}^{\mathrm{h}} \mathrm{a}^{1} \mathrm{p}^{\mathrm{h}} \partial \mathrm{y}^{1} \quad \text { 'very gray/pale' (especially referring to skin) } \\
& \mathrm{p}^{\mathrm{h}} \mathrm{a}^{1} \quad \text { 'gray' } \rightarrow \mathrm{p}^{\mathrm{h}} \mathrm{a}^{1} \mathrm{p}^{\mathrm{h}} \mathrm{Ew}^{3} \text { 'very gray' } \\
& \mathrm{p}^{\mathrm{h}} \mathrm{a}^{1} \quad \text { 'gray' } \rightarrow \mathrm{p}^{\mathrm{h}} \mathrm{a}^{1} \mathrm{p}^{\mathrm{h}} \mathrm{ok}^{7} \quad \text { 'very gray' (often referring to a distant, misty } \\
& \text { scene) }
\end{aligned}
$$

(8) $\underline{x o m}^{3}$ :

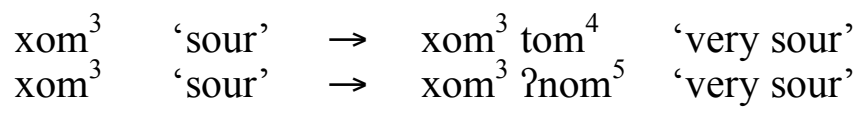

The intensifiers (exemplified in (7-8)) follow general guidelines (rhyme, alliteration, TETU, "Copy But Don't Repeat"), yet the specific features of a given intensifier may vary within those general guidelines. For example, in rhyming intensifiers, TETU encourages a coronal onset, yet the specific choice of coronal varies.

Alliterative intensifiers further illustrate this patterned variety on the tonal level. Stanford observes that the tone of an alliterative intensifier and the tone of its base usually come from the same side of the tone split discussed above. In other words, both are usually either evennumbered tones or odd-numbered tones. Thus, the tones of alliterative intensifiers exhibit patterned variety: the specific choice of intensifier tone can vary, but it usually must stay within the same side of the tone split, even or odd.

Stanford's analysis may be confirmed through future cross-linguistic comparisons. Phenomena that appear to be at least generally similar to Sui adjective intensifiers have been reported in nearby Tai-Kadai languages such as Bouyei (Yu et al. 1994), but no data are 
available for comparison. Vietnamese may also have similar adjective intensification (Thompson 1965, James Kirby personal communication). Thus, a cross-examination of the Sui data with other languages may yield further insights in the future.

\section{The lexicon}

The data entries provided here represent phonetic observation of the pronunciation of a native male Sui speaker in Ljaj Ku Tsong village, July 2004. The author collected 400 intensifiers from that speaker with the goal of providing the first detailed set of data representing a Sui speaker's intensifier system. Prior work includes Wei (1999), who provides an initial description of about 20 Sui intensifiers. Two general Sui dictionaries (Burusphat, Wei, \& Edmondson 2003 and Zeng \& Yao 1996) also include intensifiers in their entries. However, such collections sometimes have a mix of dialect variants or historical variants, especially since intensifiers can vary in subtle ways from village to village. Therefore, the author set out to establish a single, detailed intensifier lexicon representing the synchronic lexicon of a single speaker.

Future phonological analysis of Sui may provide insight into transcription decisions for features such as the length of /a:/ and the status of onset glides. The data set is divided into two main categories, the Alliterative Class and the Rhyming Class, and then further subdivided by morpho-phonological features. The small class of intensifiers with no base-reduplicant phonological resemblance is listed separately (the No-Pattern Class).

For all adjective intensifying expressions, the leftmost syllable is assumed to represent a monosyllabic adjective unless otherwise indicated. When an expression has more than two syllables, an underline is used to indicate which pair of syllables belong to the given category being analyzed in that section.

As noted above, a single base adjective often has more than one possible choice of intensifier. In such cases, each intensifier is listed in its appropriate category below. When available, further information is provided to show semantic/pragmatic contrasts between such different intensifier options for a single base adjective.

"Variant" refers to a minor alternation in pronunciation of a given entry that the consultant views as equivalent to his primary pronunciation.

\subsection{The Alliterative Class}

The intensifiers in the alliterative class are organized in the following groups (where "checked" refers to syllables with $-p$, $-t$, $-k$ in syllable final position):

1. Checked base syllable, unchecked reduplicant syllable

2. Checked base, checked reduplicant

3. Unchecked base, checked reduplicant

4. Unchecked base, unchecked reduplicant:

4.1 Nasal-final base, nasal-final reduplicant

4.2 Nasal-final base, vowel/glide-final reduplicant

4.3 Vowel/glide-final base, nasal-final reduplicant

4.4 Vowel/glide-final base, vowel/glide-final reduplicant 
In addition to the adjective intensifiers, a few alliterative nouns and other word classes are included for future analysis, e.g., $2 \mathrm{net}^{7} \mathrm{no}^{3}$ 'swing' (n.). Such words could share similar alliterative origins as the adjective intensifiers since Sui is otherwise largely monosyllabic.

\subsubsection{Checked base, unchecked reduplicant}

\begin{tabular}{|c|c|}
\hline ra:t ${ }^{7}$ sow ${ }^{1}$ & 'very nimble, agile' (general use) \\
\hline 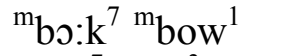 & 'very protruding, having many protrusions' (general use) \\
\hline ?лер ${ }^{7}$ реле $^{3}$ & 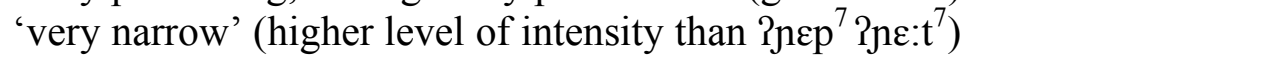 \\
\hline Pnet ${ }^{7} \mathrm{po}^{3}$ & 'a swing' (n.) \\
\hline Pbok $^{7}$ Pbow $^{1}$ & 'very coarse' (for small objects or tabletops) \\
\hline $\operatorname{Pda\eta }^{1} \mathrm{t}^{\mathrm{h}} \mathrm{ak}^{7} \mathrm{t}^{\mathrm{h}} \varepsilon \mathrm{j}^{1}$ & 'very bright' ('Mday' 'bright') \\
\hline $\operatorname{nak}^{7} \mathrm{j}_{0} \varepsilon \mathrm{n}^{1}$ & 'very coarse, rough' \\
\hline $\mathrm{j}_{0} \varepsilon: \mathrm{t}^{7} \mathrm{j}_{\mathrm{o}} \varepsilon \mathrm{j}^{1}$ & 'sealed very tightly' (higher intensity than no $_{0}: \mathrm{t}^{7} \mathrm{n}_{\circ} \mathrm{ow}{ }^{1}$ ) \\
\hline $\mathrm{j}_{0} \varepsilon: \mathrm{t}^{7} \mathrm{j}_{0} \mathrm{ow}{ }^{1}$ & 'sealed very tightly' (general use) \\
\hline $\mathrm{n}_{\mathrm{o}} \varepsilon \mathrm{t}^{7} \mathrm{j}_{\mathrm{o}} \varepsilon \mathrm{j}^{1}$ & 'sealed very tightly' \\
\hline nit $^{7} \mathrm{j}_{0}^{\circ} \rho^{3}$ & 'very cold' (weather) \\
\hline Pjet ${ }^{7^{\circ}} \mathrm{pjo} \mathrm{o}^{3}$ & 'very long ago' \\
\hline $\operatorname{lap}^{7} 1 \mathrm{en}{ }^{5}$ & 'very chatty, talkative' (derogatory) \\
\hline $\mathrm{l}^{\mathrm{j}} \varepsilon \mathrm{k}^{8} \mathrm{li}_{\mathrm{j}}^{\mathrm{uj}} \mathrm{j}^{2}$ & 'very strong' (general use) \\
\hline $1^{\mathrm{j}} \varepsilon \mathrm{p}^{7} 1^{\mathrm{j}} \mathrm{u}^{3}$ & $\begin{array}{l}\text { 'very remote, very faraway place' }\left(\mathrm{l}^{\mathrm{j}} \mathrm{ep}{ }^{7} \text { is not attested as a monosyllabic }\right. \\
\text { adjective) }\end{array}$ \\
\hline $1^{\mathrm{j}} \varepsilon \mathrm{t}^{7} 1^{\mathrm{j}} \mathrm{aw}^{3}$ & $\begin{array}{l}\text { 'hypocritical, false display of affection' }\left(\mathrm{l}^{\mathrm{j}} \mathrm{aw}^{3} \text { is not otherwise attested in }\right. \\
\text { this region, but it appears in other dialects as } l^{\mathrm{j}} \mathrm{aw}^{3} \text { 'proud') }\end{array}$ \\
\hline $1^{\mathrm{j}} \varepsilon^{7} 1^{\mathrm{j}} \mathrm{om}^{1}$ & 'very proud' \\
\hline $\mathrm{l}^{\mathrm{j}} \mathrm{ok}^{7} 1^{\mathrm{j}} \varepsilon \mathrm{n}^{1}$ & 'very sweaty' \\
\hline $\mathrm{mat}^{7} \mathrm{~m}_{0} \varepsilon \mathrm{w}^{1}$ & 'very dirty (derogatory, e.g., an animal or person's face) \\
\hline $\mathrm{mok}^{7} \mathrm{mom}^{2}$ & 'very fierce, brave' (can refer to actions, unlike $\mathrm{mok}^{7}$ tcok ${ }^{8}$ ) \\
\hline $\mathrm{mok}^{7}$ mow $^{2}$ & 'very fierce, brave, greedy' (may be related to $\mathrm{mow}^{2}$ in $\mathrm{q}^{\mathrm{h}} \mathrm{a}^{1}$ mow ${ }^{2}$ 'greedy') \\
\hline $\mathrm{pa}: \mathrm{k}^{8} \mathrm{po}^{2}$ & 'very white' (often used to refer to skin) \\
\hline pa:k ${ }^{8}$ pəๆ $^{4}$ & 'very white' (general use) \\
\hline$q^{h} o p^{7} q^{h} \varepsilon j^{5}$ & $\begin{array}{l}\text { 'very rugged' (of mountain) ( } \mathrm{q}^{\mathrm{h}} \mathrm{op}^{7} \text { is not attested as a monosyllabic } \\
\text { adjective) }\end{array}$ \\
\hline $\mathrm{q}^{\mathrm{h}} \mathrm{at}^{7} \mathrm{q}^{\mathrm{h}} \mathrm{ow}{ }^{1}$ & 'very bitter' \\
\hline sut $^{7}$ som $^{1}$ & 'very hot' \\
\hline $\operatorname{sət}^{7} \mathrm{sew}^{3}$ & 'very pretty, cute' (esp. little animals or children) \\
\hline $\mathrm{t}^{\mathrm{j}} u \mathrm{t}^{8} \mathrm{t}^{\mathrm{j}} \mathrm{aw}{ }^{4}$ & 'very wrinkled' (e.g., clothes) (higher intensity than $\left.\mathrm{t}^{\mathrm{j}} \mathrm{ut}^{8} \mathrm{t}^{\mathrm{j}} \varepsilon \mathrm{t}^{8}\right)$ \\
\hline $\mathrm{t}_{6 \mathrm{ak}}{ }^{7} \mathrm{t} 6 \mathrm{om}^{3}$ & 'very stiff, inflexible' (general use) \\
\hline $\mathrm{t}^{\mathrm{h}} \mathrm{ak}^{7} \mathrm{t}^{\mathrm{h}} \mathrm{aw}^{1}$ & $\begin{array}{l}\left.\text { 'very clear and bright' (less common than } \mathrm{t}^{\mathrm{h}} \mathrm{ak}^{7} \mathrm{t} \varepsilon \mathrm{j}^{1}\right)\left(\mathrm{t}^{\mathrm{h}} \mathrm{ak}^{7} \text { is not attested as }\right. \\
\text { a monosyllabic adjective) }\end{array}$ \\
\hline $\mathrm{t}^{\mathrm{h}} \mathrm{ak}^{7} \mathrm{t}^{\mathrm{h}} \varepsilon \mathrm{j}^{1}$ & $\begin{array}{l}\text { 'very clear and bright' (general use) ( } \mathrm{t}^{\mathrm{h}} \mathrm{ak}^{7} \text { is not attested as a monosyllabic } \\
\text { adjective) }\end{array}$ \\
\hline
\end{tabular}




\subsubsection{Checked base, checked reduplicant}

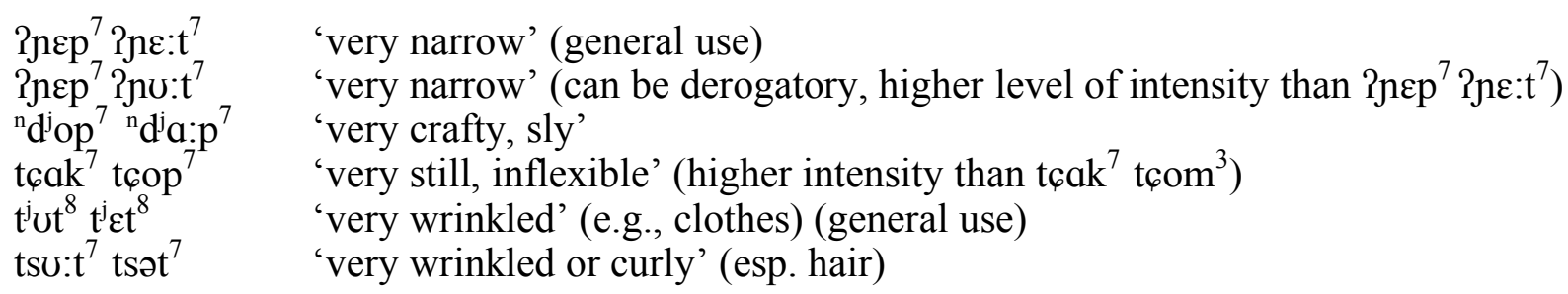

\subsubsection{Unchecked base, checked reduplicant}

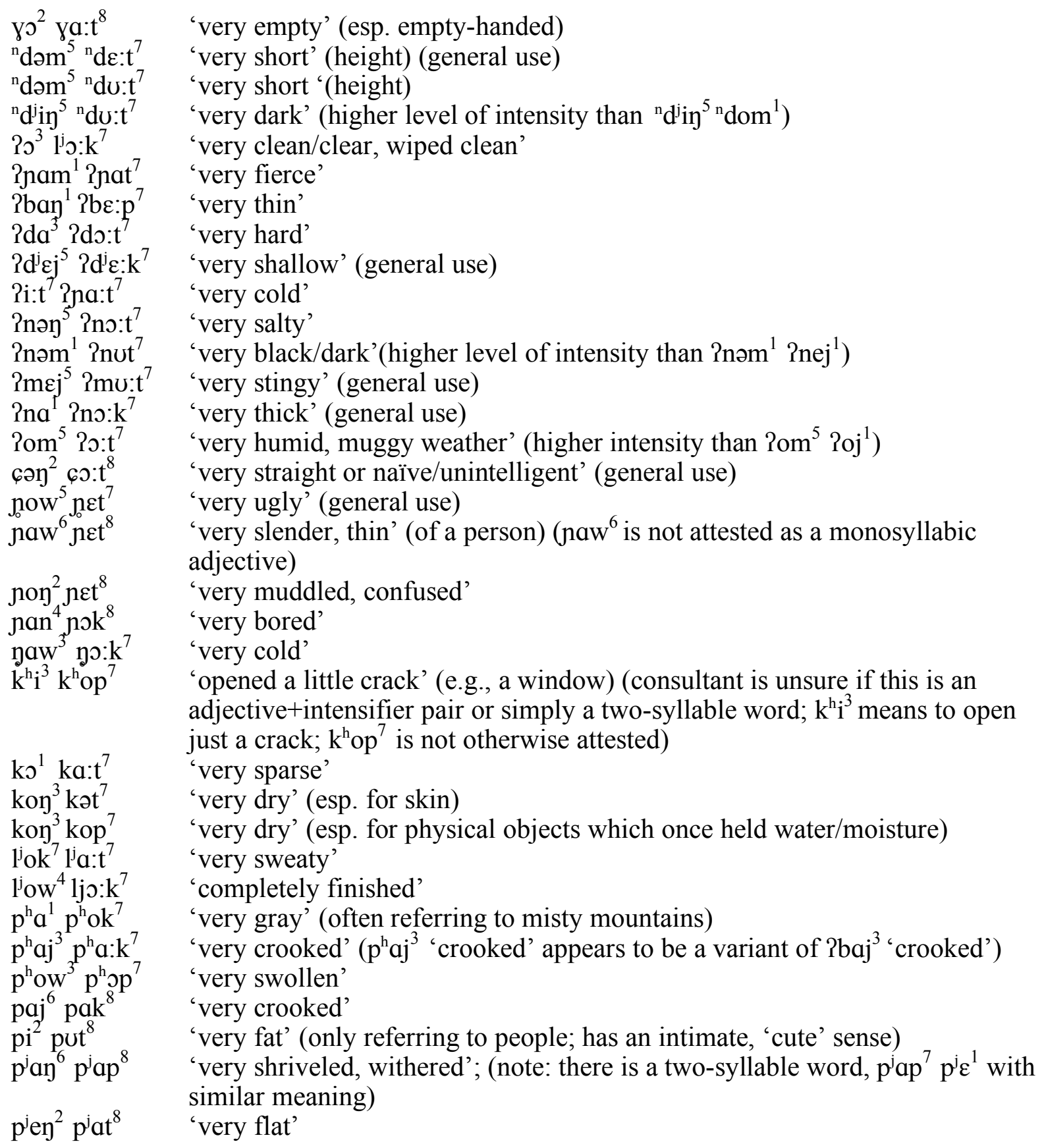




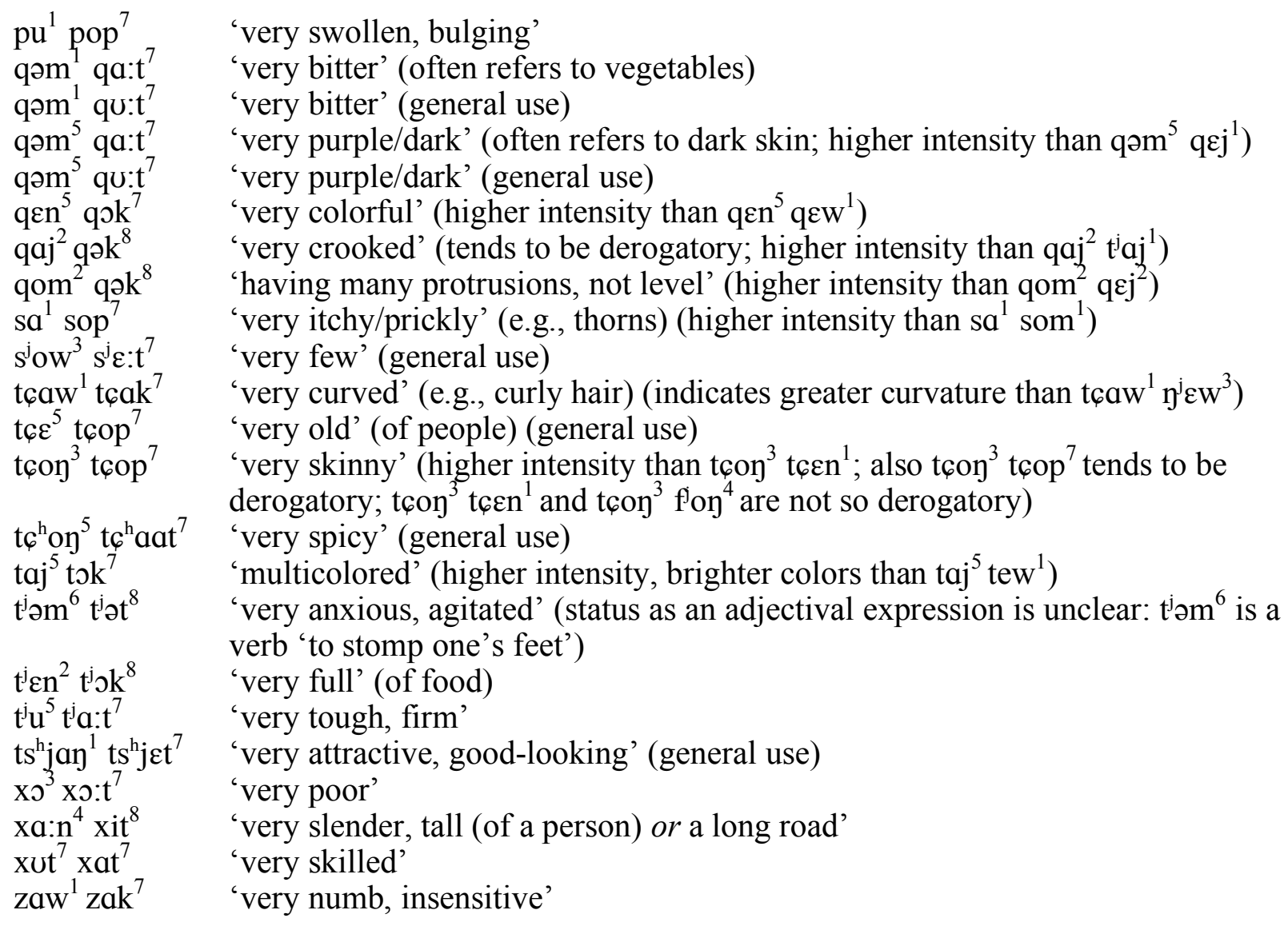

\subsubsection{Unchecked base, unchecked reduplicant}

\subsubsection{Nasal-final base, nasal-final reduplicant}

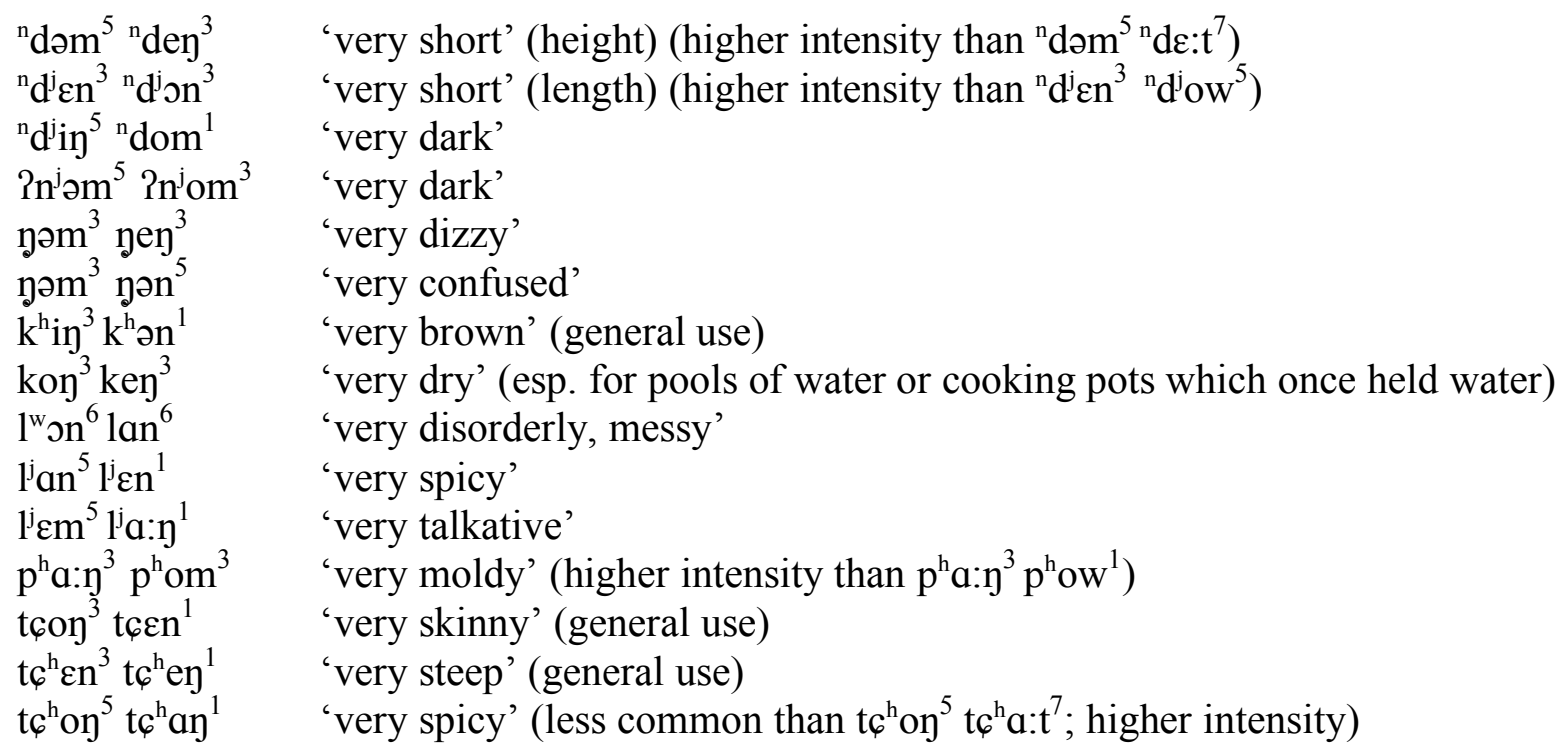


$\mathrm{t}^{\mathrm{h}} \mathrm{en}^{3} \mathrm{t}^{\mathrm{h}} \mathrm{om}^{1} \quad$ 'puffed, bulging, not wrinkled' (general use)

$\operatorname{tom}^{5}$ tom $^{3} \quad$ 'very dark' (weather)

$\operatorname{va\eta }^{1} v^{j} \varepsilon^{5} \quad$ 'very tall' ( $\operatorname{va\eta }^{1} v^{j} \varepsilon n^{5}$ does not include a sense of 'strong', unlike va: $\eta^{1}$ tca: $\eta^{2}$ )

\subsubsection{Nasal-final base, vowel/glide-final reduplicant}

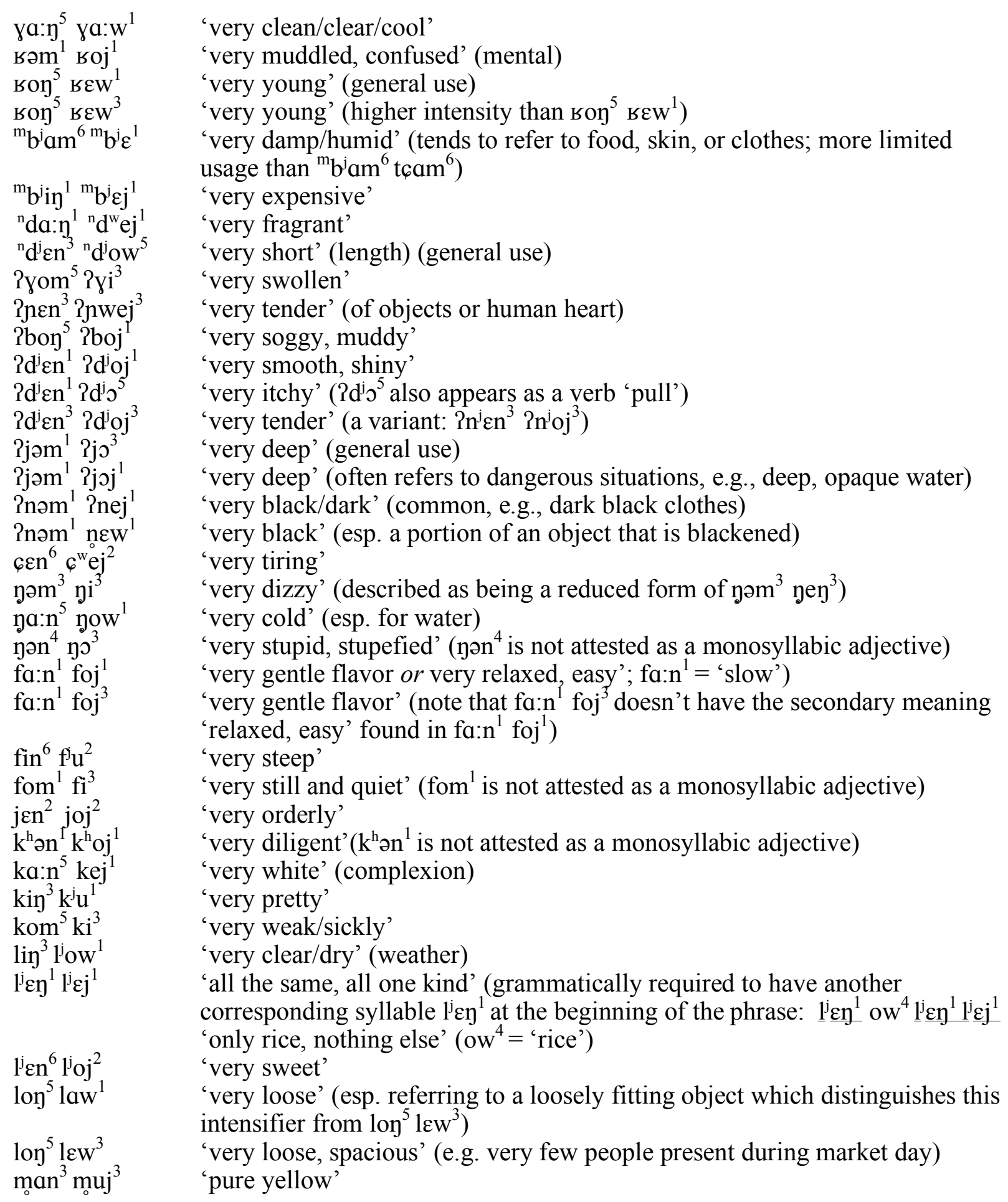




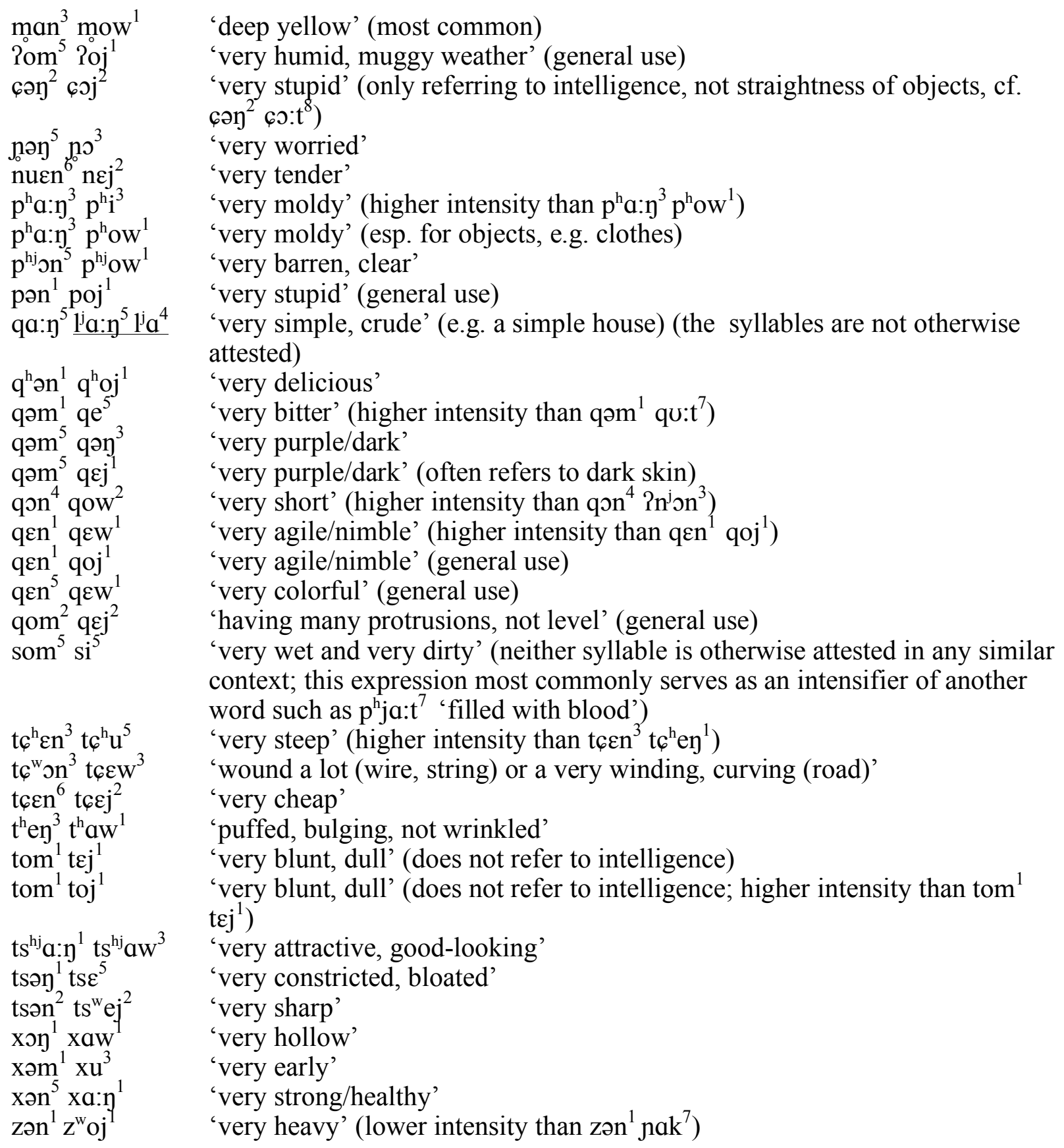

\subsubsection{Vowel/glide-final base, nasal-final reduplicant}

уо ${ }^{6}$ ya: $\eta^{4} \quad$ 'very leaky' (general use)

${ }^{\mathrm{m}} \mathrm{bu}^{3}{ }^{3} \mathrm{~b}^{1}{ }^{1} \quad$ 'very protruding' (often refers to small objects, food)

${ }^{n} \mathrm{daw}^{5}{ }^{\mathrm{n}} \mathrm{d}^{\mathrm{j} a} \mathrm{a} \mathrm{y}^{1} \quad$ 'to move around with rolling, rocking motion' (adjective/verb status unclear)

Pyaj $_{5}^{3}$ Pyəj $^{2}$ 'very long' (general use)

$2 b^{j} a^{5} 2 b^{j} \varepsilon n^{3} \quad$ 'very smooth' (e.g., skin)

$2 \mathrm{~d}^{\mathrm{j}} \varepsilon \mathrm{j}^{5} \mathrm{Pd}^{\mathrm{j}} \mathrm{cm} \mathrm{\eta}^{3} \quad$ 'very shallow' (higher intensity than $\mathrm{Pd}^{\mathrm{j}} \varepsilon \mathrm{j}^{5} \mathrm{Pd}^{\mathrm{j}} \varepsilon: \mathrm{k}^{7}$ )

$6 a^{1} \operatorname{c\varepsilon n}^{1} \quad$ 'very sharp'

$\mathrm{cu}^{1} \operatorname{cin}^{5} \quad$ 'very green' 


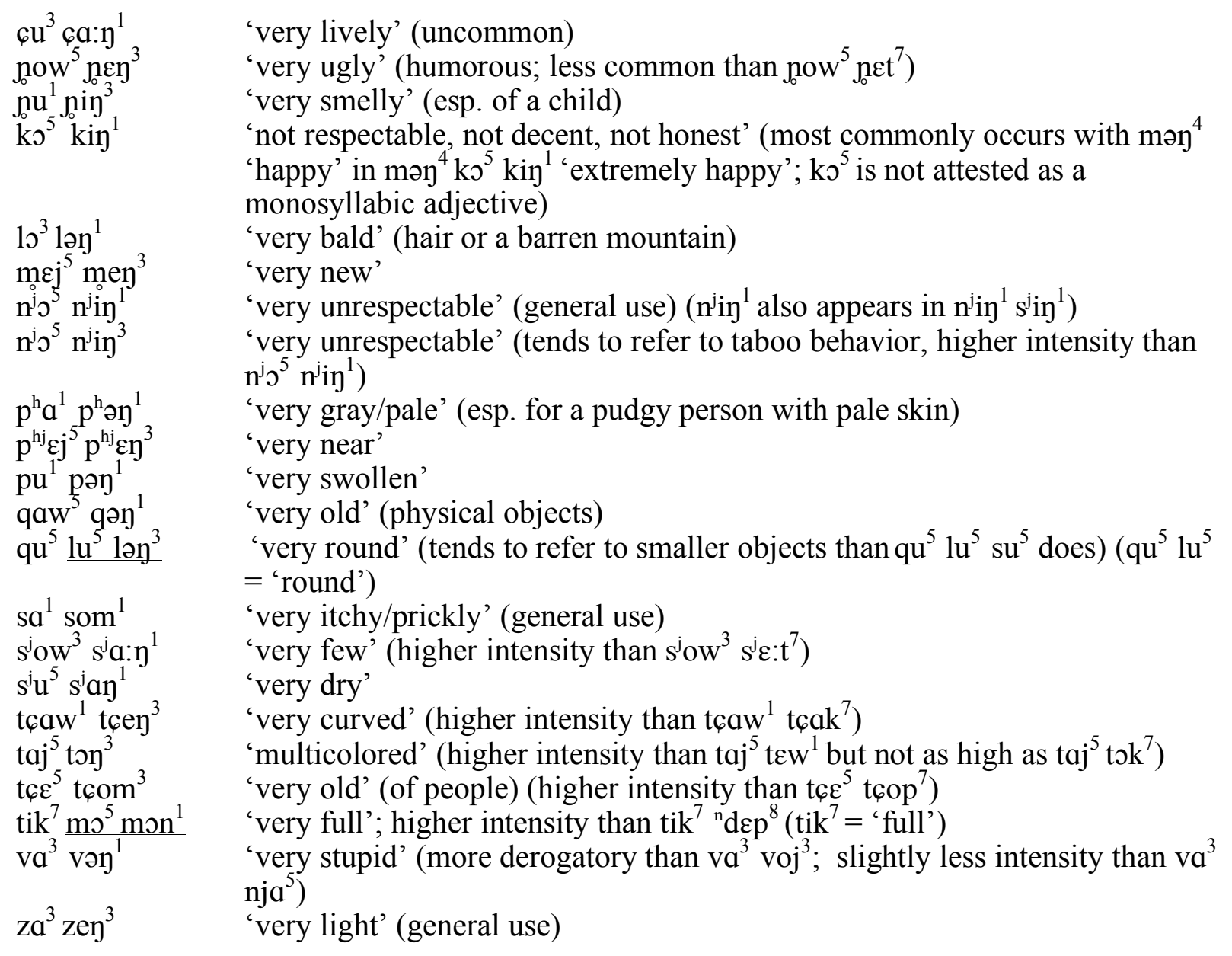

\subsubsection{Vowel/glide-final base, vowel/glide-final reduplicant}

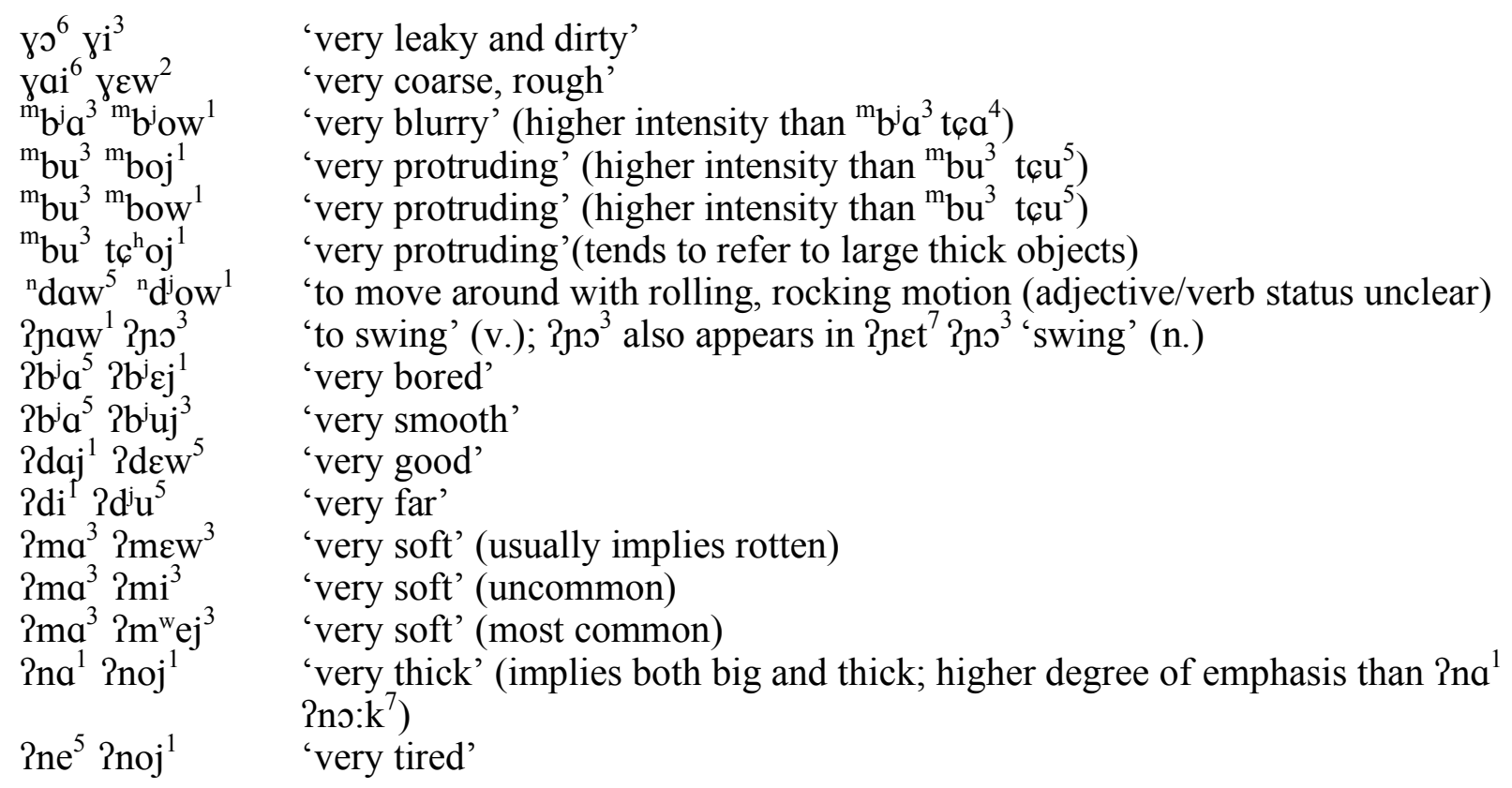


$6 \mathrm{a}^{1} 6 \mathrm{u}^{5}$

$\mathrm{naj}^{4} \mathrm{new}^{1}$

$\mathrm{fe}^{\mathrm{f}} \mathrm{fi}^{3}$

$\mathrm{fe}^{3}$ foj $^{1}$

$\mathrm{k}^{\mathrm{h}} \mathrm{a}^{5} \mathrm{k}^{\mathrm{h}} \mathrm{ej}^{1}$

$n o^{2} n j^{2}$

$\mathrm{p}^{\mathrm{h}} \mathrm{a}^{1} \mathrm{p}^{\mathrm{h}} \varepsilon \mathrm{w}^{3}$

$\mathrm{p}^{\mathrm{h}} \mathrm{a}^{1} \mathrm{p}^{\mathrm{h}} \mathrm{oj}{ }^{1}$

pha:t $\mathrm{t}^{\mathrm{h}} \mathrm{sm}^{5} \mathrm{si}^{5}$

$\mathrm{pi}^{5} \underline{\mathrm{i}^{5}} \mathrm{ljoj}^{1}$

$\mathrm{qaw}^{5} \mathrm{qe}^{5}$

tcaw ${ }^{1} \mathrm{n}^{\mathrm{j}} \mathrm{Ew}^{3}$

taj $^{5}$ tew 1

$\mathrm{ti}^{3} \mathrm{ti}^{4}$

$\mathrm{ti}^{3} \mathrm{t}^{\mathrm{j}} \mathrm{u}^{4}$

$\mathrm{ti}^{3} \mathrm{t}^{\mathrm{j}} \mathrm{u}^{5}$

tiw $^{3}$ to $^{5}$

$\mathrm{va}^{3} \mathrm{voj}^{3}$

$\mathrm{za}^{3} \mathrm{zu}^{\mathrm{I}}$

zaw $^{1} \mathrm{ze}^{5}$ 'very sharp' (general use) ( $c u^{5}$ also appears in the lexicon as 'really' (adv.), but the consultant views $\varphi \mathrm{a}^{1} \mathrm{cu}^{5}$ as having "a true intensifier here", not simply the adverb 'really')

'very dirty/blackened'

'very late' (general use)

'very tired'

'vigorously blazing (a fire) or very greasy (food)'

'stupid, silly' ( $\mathrm{n}{ }^{2}$ also appears in tom ${ }^{1} \mathrm{no}^{2} \mathrm{~s}^{2}$ 'very stupid; $\mathrm{n} \mathrm{s}^{2}$ has been observed as an independent adjective)

'very gray' (esp. gray ash/powder spots on clothing) (variant: $\mathrm{p}^{\mathrm{h}} \mathrm{a}^{1} \mathrm{p}^{\mathrm{h}} \varepsilon \mathrm{w}^{1}$ )

'very gray' (esp. gray ash/powder spots on clothing)

'bleeding a lot' (adjective/verb status unclear) (variant: $\mathrm{so}^{5} \mathrm{si}^{5}$ )

'very messy' (cf. $\mathrm{pi}^{5} \mathrm{li}^{5} \mathrm{si}^{5}$ which includes the sense 'narrow') (variants: $\mathrm{p}^{\mathrm{h}} \mathrm{i}^{5}$ $1 i^{5}{ }^{\mathrm{j}} \varepsilon j^{1}$ and $\left.\mathrm{p}^{\mathrm{h}} \mathrm{i}^{\mathrm{S}} \mathrm{il}^{\mathrm{5}} \mathrm{l}^{\mathrm{j}} \varepsilon \mathrm{j}^{\mathrm{1}}\right)$

'very old' (physical objects) (higher intensity than qaw ${ }^{5}$ qəy $^{1}$ )

'curved, bent' (not a very high degree of curvature)

'multicolored' (general use, but relatively shallow colors)

'very small' (general use)

'very small' (higher intensity than $\mathrm{ti}^{3} \mathrm{t}^{\mathrm{j}} \mathrm{u}^{5}$ and $\mathrm{ti}^{3} \mathrm{t}^{\mathrm{j}} \mathrm{u}^{4}$ )

'very small' (general use)

'very dry' (general use)

'very stupid' (more subtle connotation than $\mathrm{va}^{3}$ vəy ${ }^{1}$ )

'very light' (also: flighty, frivolous attitude)

'very numb, insensitive' (less intensity than zaw ${ }^{1} \mathrm{zak}^{7}$ )

\subsection{The rhyming class}

The intensifiers in the rhyming class are organized into six groups: intensifiers with labial onsets (Group 1), dorsal onsets (Group 2), glottal onsets (Group 3), coronal onsets (Group 4), fully reduplicated pairs (Group 5), and three-syllable expressions (Group 6). Within those groups, intensifiers are further differentiated as sets of intensifiers sharing similar onset feature changes. Finally, within some sets, intensifiers are differentiated into subsets of similar feature changes.

In a few cases where a pair of intensifiers rhyme with each other but do not rhyme with the base adjective, then the rhyming pair being analyzed in that section is underlined, e.g., tom ${ }^{1}$ 'dull' $\rightarrow$ tom $^{1} \mathrm{no}^{2} \mathrm{so}^{2}$ 'very dull'.

The third syllables of three-syllable rhyming expressions (e.g., mow ${ }^{1}$ 'rash (adj.)' $\rightarrow$ mow $^{1}$ ${ }^{10}{ }^{1}$ 'very rash' $\rightarrow$ mow $^{1}$ low $^{1}$ tow $^{2}$ 'extremely rash') are analyzed as a separate set. The two rhyming syllables being analyzed in that section are underlined, e.g., mow ${ }^{1}$ low $^{1}$ tow $^{2}$. In addition, for a few intensifiers where speakers report that the rhyming syllables cannot be

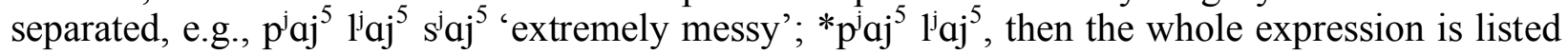
along with the more typical two-syllable expressions with the first two syllables underlined to show they are being analyzed in that section, e.g., $\mathrm{p}^{\mathrm{j}} \mathrm{aj}^{5} \mathrm{l}^{\mathrm{j} a j^{5}} \mathrm{~s}^{\mathrm{j}} \mathrm{aj}{ }^{5}$. 


\section{Group 1. Labial base onsets}

\section{Set 1.1: Voiced labial becomes a voiceless coronal obstruent}

Feature changes in this set:

[+voice] $\rightarrow$ [-voice $]$

[labial] $\rightarrow$ [coronal]

Variation in Onset Place: 7 cases of [tc], 1 case of [tj], 1 case of [t $\left.\epsilon^{h}\right], 1$ case of [t]

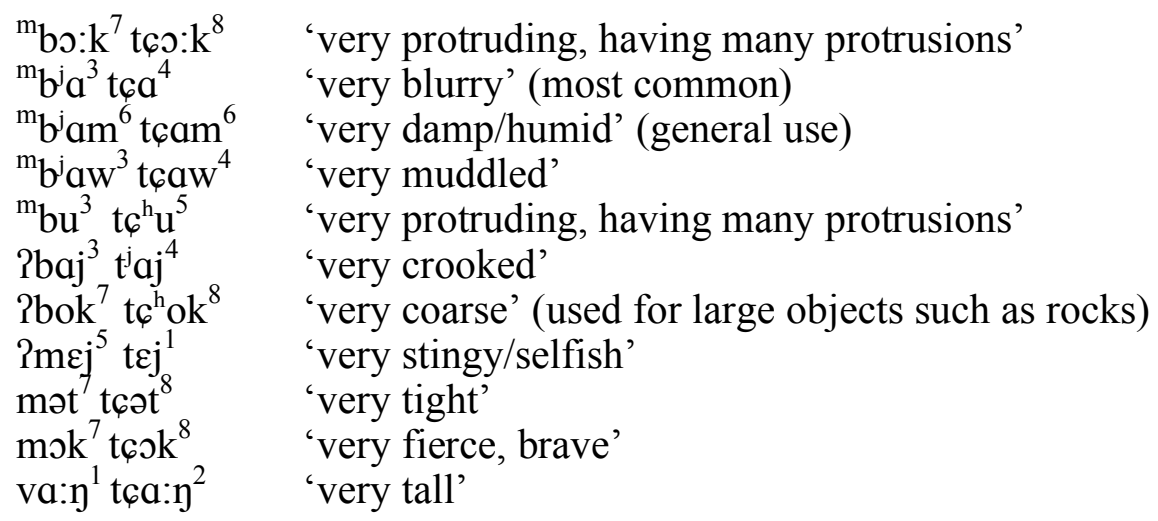

Set 1.2: Voiceless labial becomes a voiced coronal sonorant

Feature changes in this set:

[-voice $] \rightarrow[+$ voice $]$

[labial $] \rightarrow[$ coronal $]$

[-lat $] \rightarrow[+$ lat $]$ (exception: pən $^{1}$ ?nən ${ }^{1}$ )

[-son $] \rightarrow[+$ son $]$ (exceptions: mow ${ }^{1}$ low $^{1}$ )

$\operatorname{pon}^{1}{ }^{2} \operatorname{Pon}^{1} \quad$ 'very stupid'

$\mathrm{pi}^{2} \mathrm{p}^{\mathrm{j}} \mathrm{u}^{1} \mathrm{l}^{\mathrm{j}} \mathrm{u}^{1} \quad$ 'very fat' ( $\mathrm{pi}^{2}$ ' $\mathrm{fat}$ ') ( $\mathrm{p}^{\mathrm{j}} \mathrm{u}^{1}$ is not attested as a monosyllabic adjective)

$\mathrm{pi}^{5} \mathrm{li}^{5} \quad$ 'messy' (e.g. a messy desktop) $\left(\mathrm{pi}^{5}\right.$ is not attested as a monosyllabic adjective)

$p^{j} a j^{5}{ }^{j}{ }^{j} j^{5} s^{j} a j{ }^{5} \quad$ 'very messy' (e.g. messy writing or messy soup, differs from $\mathrm{pi}^{5} \mathrm{li}^{5} \mathrm{si}^{5}$ or $\mathrm{p}^{\mathrm{j} a} \mathrm{a} \mathrm{n}^{6} \mathrm{l}^{\mathrm{j}} \mathrm{a}: \mathrm{n}^{6} \mathrm{na}^{\circ} \mathrm{n}^{6} ; \mathrm{p}^{\mathrm{j}} \mathrm{aj} \mathrm{j}^{5}$ is not attested as a monosyllabic adjective)

$p^{j} a: n^{6} l^{j} a: n^{6}{ }_{0} a: n^{6} \quad$ 'very messy' (e.g. a messed up pile of books) ( $p^{j} a: n^{6}$ is not attested as a monosyllabic adjective)

$\mathrm{p}^{\mathrm{j}} \varepsilon: \mathrm{k}^{7} \mathrm{l}^{\mathrm{j}} \varepsilon: \mathrm{k}^{7} \quad$ 'very dirty'

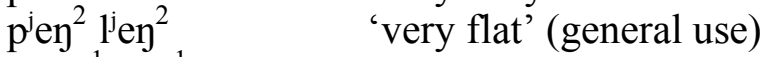

mow ${ }^{1}$ low 1 'very crude' (derogatory)

fa: $\eta^{3} 1^{j} \mathrm{a}: \eta^{2} \quad$ 'very wide'

fa: $n^{1} 1^{j} a: n^{2}$

'very slow or gentle flavor' (e.g. alcohol) (Note that fa: $n^{1} 1^{\mathrm{j}} \mathrm{a}: \mathrm{n}^{2}$ doesn't have the secondary meaning 'relaxed, easy' found in fa: $\mathrm{n}^{1} \mathrm{foj}^{1}$ ) 
Unclassified:

$\mathrm{p}^{\mathrm{h} a j^{3}} \operatorname{taj}^{4}$ 'very crooked' (the base may be in free variation with $\mathrm{Pbaj}^{3}$ )

fa: $t^{8}$ ya: $t^{8} \quad$ 'very disheveled, weary' (fa: $t^{8}$ is not attested as a monosyllabic adjective)

\section{Group 2. Dorsal base onsets}

\section{Set 2.1: Voiced dorsal becomes a voiceless coronal}

Feature changes in this set:

[dorsal] $\rightarrow$ [coronal]

Other feature changes are listed below by subset.

Subset 2.1.1:

[+voice $] \rightarrow[$-voice $]$

$[+$ cont $] \rightarrow[$-cont $]$

ва: $\mathrm{t}^{7}$ tca: $\mathrm{t}^{8} \quad$ 'very agile', also 'hurried, hasty'

Subset 2.1.2:

[+voice $] \rightarrow[$-voice $]$

$[-$ nasal $] \rightarrow[+$ nasal $]$

Pyaj $^{3}$ naj $^{1}$ 'very long'

Subset 2.1.3:

$[+$ voice $] \rightarrow[$-voice $]$

$[+$ nasal $] \rightarrow[-$ nasal $]$

ya: $\mathrm{t}^{7}$ ta: $\mathrm{t}^{7} \quad$ 'very still and quiet' (na: $\mathrm{t}^{7}$ is not attested as a monosyllabic adjective)

pot $^{8}$ sət $^{8} \quad$ 'very stupid'

tom $^{1} \mathrm{yo}^{2} \mathrm{so}^{2} \quad$ 'very dull' (of a knife), 'unintelligent' (of a person) (tom ${ }^{1}$ 'dull')

\section{Set 2.2: Voiceless dorsal becomes a voiced coronal}

Feature change in this set: [dorsal] $\rightarrow$ [coronal]. Other feature changes are listed below by subset.

Subset 2.2.1:

$[$-voice $] \rightarrow[+$ voice $]$

$[$-cont $] \rightarrow[+$ cont $]$

$[-$ lat $] \rightarrow[+$ lat $]$

$[$-son $] \rightarrow[+$ son $]$

In this subset, the bases are not attested as monosyllabic adjectives. 


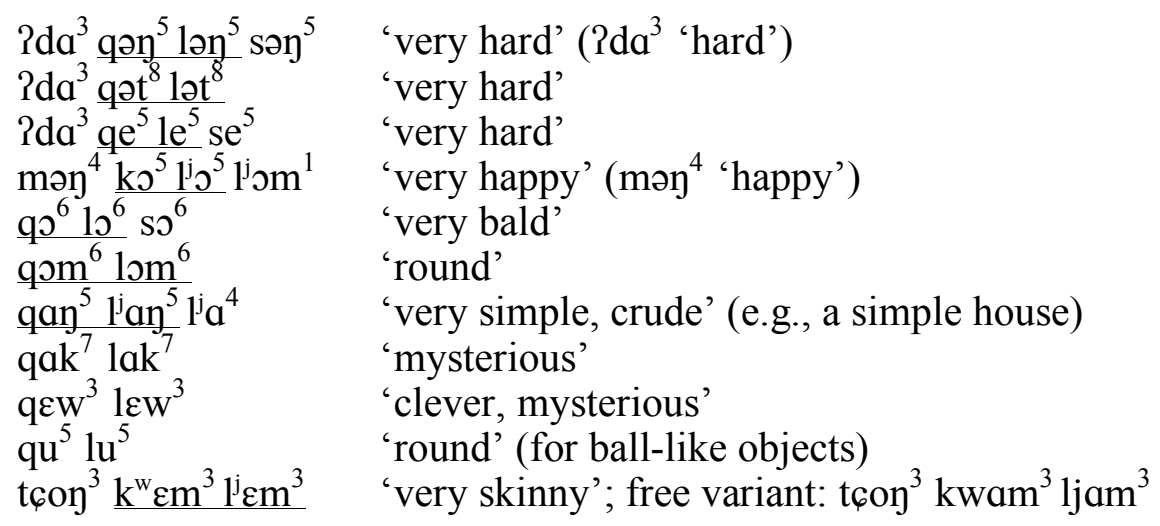

Subset 2.2.2:

$[$-voice $] \rightarrow[+$ voice $]$

$[-$ cont $] \rightarrow[+$ cont $]$

$[$-nasal $] \rightarrow[+$ nasal $]$

$[-$ Son $] \rightarrow[+$ son $]$

$2 \mathrm{ma}^{3} \mathrm{k}^{\mathrm{w}} \mathrm{et}^{8} \mathrm{n}^{\mathrm{j}} \mathrm{ct}^{8} \quad$ 'very soft' ( $\mathrm{Pma} \mathrm{m}^{3}$ 'soft') ( $\mathrm{k}^{\mathrm{w}} \mathrm{ct}^{8}$ is not attested as a monosyllabic adjective)

$\mathrm{x}^{7} \mathrm{k}^{7} \mathrm{kt}^{\mathrm{w}} \mathrm{nat}^{8} \quad$ 'very lazy' ( $\mathrm{mma}^{3}$ 'soft') $\left(\mathrm{k}^{\mathrm{w}} \mathrm{at}^{8}\right.$ is not attested as a monosyllabic adjective)

$\mathrm{q}^{4} \mathrm{n}^{4} \mathrm{n}^{\mathrm{j}} \mathrm{n}^{3} \quad$ 'very short' (general use)

xom $^{3}$ ?nom ${ }^{5} \quad$ 'very sour' (higher intensity than xom ${ }^{3} \mathrm{p}^{\mathrm{j} a} \mathrm{a} \mathrm{t}^{7}$ )

Subset 2.2.3:

$[-$ lat $] \rightarrow[+$ lat $]$

$[-$ son $] \rightarrow[+$ son $]$

$\mathrm{x} 0^{3} \mathrm{j}^{\mathrm{j}} \mathrm{o}^{4} \quad$ 'very poor'

$\operatorname{xop}^{7} 1^{\mathrm{j} o p^{8}} \quad$ 'very dizzy with success' (xop ${ }^{8}$ is not attested as a monosyllabic adjective)

Subset 2.2.4:

$\mathrm{pi}^{2} \mathrm{ka}^{5}{ }^{n} \mathrm{~d}^{\mathrm{j}} \mathrm{a}^{5}{ }^{\mathrm{n}} \mathrm{d}^{\mathrm{j}} \mathrm{om}{ }^{1}$ 'very fat' ( $\mathrm{pi}^{2}$ 'fat') ( $\mathrm{ka}^{5}$ is not attested as a monosyllabic adjective)

\section{Set 2.3: Voiceless dorsal becomes a voiceless coronal obstruent}

Feature changes are listed by subset below.

Subset 2.3.1:

$[+$ cont $] \rightarrow[-$ cont $]$

$\begin{array}{ll}\mathrm{xa}: \mathrm{n}^{3} \mathrm{t} \mathrm{j} a: \mathrm{n}^{2} & \text { 'very red' (can be derogatory) } \\ {\mathrm{x} \partial \mathrm{k}^{7}}^{\mathrm{t}} \mathrm{t}^{8} \mathrm{k}^{8} & \text { 'very crowded, constricted' (general use) }\end{array}$ 
$\operatorname{xom}^{3}$ tom $^{4} \quad$ 'very sour' (higher intensity than xom ${ }^{3}$ pja: $^{7}$ )

xom $^{3}$ tom $^{5}$ ?nom ${ }^{5}$ som $^{5}$ 'very sour' (higher intensity than xom ${ }^{3}$ ?nom $^{5}$ )

Subset 2.3.2:

[dorsal $] \rightarrow[$ coronal $]$

$[$-cont $] \rightarrow[+$ cont $]$

$[$-strid $] \rightarrow[+$ strid $]$

In this subset, the bases are not attested as monosyllabic adjectives.

$\mathrm{ko}^{5} \mathrm{~s}^{\mathrm{j}} \rho^{5} \quad$ 'to be stunned, stupefied'

$\mathrm{kə \eta}^{5} \mathrm{sə \eta}^{5} \quad$ 'can't help doing something, have no alternative'

Subset 2.3.3:

[dorsal] $\rightarrow$ [coronal]

$[+$ asp $] \rightarrow[$-asp]

$\mathrm{k}^{\mathrm{h}} \mathrm{in}^{3} \operatorname{tin}^{4}$ 'very brown'

Subset 2.3.4

[dorsal] $\rightarrow$ [coronal]

$[+\mathrm{bk}] \rightarrow[-\mathrm{bk}]$

$\mathrm{qaj}^{2} \mathrm{t}^{\mathrm{j}} \mathrm{j}^{1} \quad$ 'very crooked' (tends to be derogatory)

\section{Set 2.4: Voiceless velar fricative becomes a voiceless uvular stop}

Feature changes in this set:

[dorsal] $\rightarrow$ [uvular]

$[+$ cont $] \rightarrow[$-cont $]$

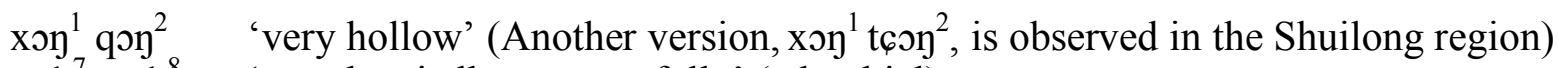
xok $^{7}$ qok $^{8} \quad$ 'very hurriedly, not carefully' (adverbial)

Set 2.5: Voiceless velar stop becomes a voiced velar fricative

Feature changes in this set:

$[$-cont $] \rightarrow[+$ cont $]$

[+asp] $\rightarrow[$-asp]

$[$-voice $] \rightarrow[+$ voice $]$

$\mathrm{k}^{\mathrm{h}} \mathrm{oj}^{3}$ үoj $^{4}$ 'very hollowed, sunken (object) or greedy' 
Set 2.6: Tone change only

$\mathrm{ko \eta}^{2} \mathrm{ko \eta}^{6} \mathrm{ko \eta}^{3} \quad$ 'very much' (only used when speaking to a child in a silly manner)

\section{Group 3. Glottal base onsets}

Feature change: [glottal] $\rightarrow$ [coronal]

Pom $^{3}$ tom 4 'very hunchbacked'

?om $^{5}$ tom $^{2} \quad$ 'very humid' (weather)

\section{Group 4. Coronal base onsets}

\section{Set 4.1: Voiceless coronal obstruent becomes coronal nasal (with same [back] feature)}

Feature changes in this set:

$[-$ son $] \rightarrow[+$ son $]$

$[$-nasal $] \rightarrow[+$ nasal $]$

$[$-voice $] \rightarrow[+$ voice $]$

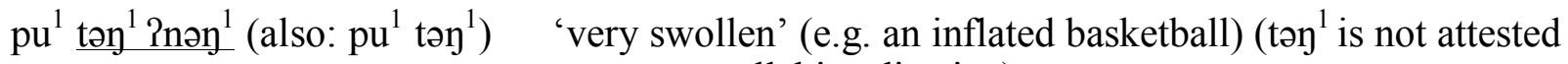
as a monosyllabic adjective)

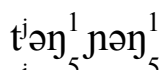

$\mathrm{t}^{\mathrm{j}} \mathrm{\eta}^{5} \mathrm{n}^{5} \mathrm{\eta}^{5}$

$\mathrm{tak}^{\mathrm{j}} \mathrm{nak}^{7}$

tom ${ }^{1}$ ?nom ${ }^{1}$

tow ${ }^{5}$ now ${ }^{5}$

xom $^{3}$ tom $^{5}$ nom som $^{5}$

$\omega ə \eta^{2} \mathrm{t}_{60 j^{2}}$ noj $^{2}$

'very long' (time)

'very full' (of food)

'very broken'

'very dull' (of a knife), also 'dumb' (of a person)

'very dull, slow' (of ability to think)

'very sour' (higher intensity than xom ${ }^{3}$ nnom $\left.{ }^{5}\right)\left(2 n o m^{5}\right.$ is not attested as a monosyllabic adjective)

'very stupid' ( $6 \ni \eta^{2}$ 'stupid') ( $\mathrm{t}_{\mathrm{coj}}{ }^{2}$ is not attested as a

$\mathrm{pi}^{2} \mathrm{t}^{\mathrm{j} \partial \eta^{2}}$ nəท $^{2}$ monosyllabic adjective)

'very fat' ( $\mathrm{pi}^{2}$ ' far') ( $\mathrm{t}^{\mathrm{j} \partial \mathrm{y}^{2}}$ is not attested as a monosyllabic adjective)

The following intensifying expressions for ${ }^{\mathrm{n}} \mathrm{dəm}^{5}$ 'short' (height) bear close phonological resemblance. The consultant reports all four expressions, but it is unclear whether they should be classified as individual entries or "free variants" of a single entry. In addition, except for tu: $\mathrm{t}^{\text {, }}$, the bases are not attested as monosyllabic adjectives.

${ }^{n} \mathrm{~d}^{5} \mathrm{t}^{5}: \mathrm{t}^{7} \mathrm{n} \varepsilon: \mathrm{t}^{7} \quad$ 'very short' (height) (' $\mathrm{dəm}^{5}$ 'short' (height))

${ }^{n}{\mathrm{~d} ə \mathrm{~m}^{5}}^{5} \mathrm{te}^{2} \mathrm{ne}^{2} \quad$ 'very short' (height) (' $\mathrm{dəm}^{5}$ 'short' (height))

${ }^{\mathrm{n}} \mathrm{d}^{\mathrm{j}} \mathrm{en}^{3} \mathrm{to}^{\mathrm{t}: \mathrm{t}^{7} \mathrm{n} \mathrm{s}: \mathrm{t}^{7}}$ 'very short' (height) ( ${ }^{\mathrm{n}} \mathrm{dəm}^{5}$ 'short' (height))

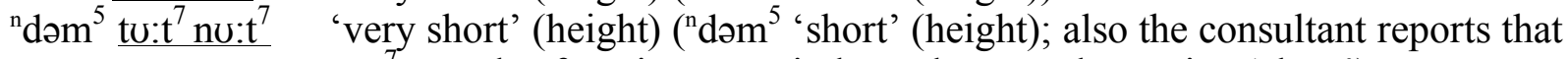
to: $\mathrm{t}^{7}$ can also function as an independent word meaning 'short') 


\section{Set 4.2: Voiceless coronal obstruent becomes a lateral}

Feature changes in this set listed below by subset.

Subset 4.2.1:

Feature changes:

$[$-voice $] \rightarrow[+$ voice $]$

$[-$ lat $] \rightarrow[+$ lat $]$

$[-$ cont $] \rightarrow[+$ cont $]$

$\varphi \eta^{2}$ tet $^{8} 1 \varepsilon t^{8} \quad$ 'very straight' (can only refer to objects) (tet ${ }^{8}$ is not attested as a monosyllabic adjective)

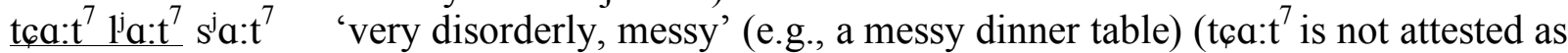
a monosyllabic adjective)

$x a: n^{3}$ ta $a: n^{2} l^{j} a: n^{2} \quad$ 'extremely red' (higher intensity than xa: $\left.n^{3} t^{j} a: n^{2}\right)\left(x a: n^{3}\right.$ 'red')

Subset 4.2.2:

Feature changes:

$[$-voice $] \rightarrow[+$ voice $]$

$[+$ strid $] \rightarrow[$-strid $]$

$\operatorname{sən}^{4}$ sop $^{7} 1^{\mathrm{j} o p^{8}}$ 'very flustered, hurried' (sən ${ }^{4}$ 'flustered, hurried') (sop is not attested as a monosyllabic adjective)

\section{Set 4.3: Nasal or lateral coronal becomes a voiceless coronal obstruent (or voiceless nasal)}

Feature changes listed by subset below.

Subset 4.3.1:

$[+$ voice $] \rightarrow[$-voice $]$

$[+$ nasal $] \rightarrow[-$ nasal $]$

$[$-strid $] \rightarrow[+$ strid $]$

[+son] $\rightarrow[$-son $]$

The bases in this set are not attested as monosyllabic adjectives.

\begin{tabular}{|c|c|}
\hline 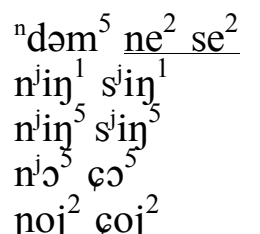 & $\begin{array}{l}\text { 'very short (height)' (" } \mathrm{d}^{2}{ }^{5} \text { 'short (heig } \\
\text { 'very filthy, unrespectable' } \\
\text { 'very filthy, unrespectable' } \\
\text { 'very filthy, unrespectable' } \\
\text { 'very stupid' }\end{array}$ \\
\hline
\end{tabular}


Subset 4.3.2:

[+voice $] \rightarrow[$-voice $]$

$[+$ lat $] \rightarrow[-$ lat $]$

$[$-strid $] \rightarrow[+$ strid $]$

[+son] $\rightarrow[-$-son $]$

$\operatorname{lot}^{8}$ sət $^{8} \quad$ 'Very blunt, stubborn'

Subset 4.3.3:

[+voice] $\rightarrow$ [-voice]

$[+$ lat $] \rightarrow[-$ lat $]$

[+son $] \rightarrow[$-son $]$

$[+$ cont $] \rightarrow[$-cont $]$

$1^{\text {w}}$ on $^{4}$ tcon $^{2}$ 'very blunt, dull' (e.g. a knife)

$1^{\mathrm{w}} \mathrm{nn}^{6} \mathrm{t}^{\mathrm{w}} \mathrm{on}^{6} \quad$ 'very disorderly, messy'

$1 \partial \eta^{5} \operatorname{to\eta }^{4} \quad$ 'very careless'

$\operatorname{lo\eta }^{5}$ tcən $^{4} \quad$ 'very straight'

$\operatorname{lap}^{7} \operatorname{tap}^{8} \quad$ 'very chatty, talkative' (derogatory)

Subset 4.3.4:

[+voice $] \rightarrow[$-voice $]$

$[+$ lat $] \rightarrow[-$ lat $]$

$[+$ son $] \rightarrow[$-son $]$

$[$-nasal $] \rightarrow[+$ nasal $]$

$[+$ cont $] \rightarrow[-$ cont $]$

$\mathrm{l}^{\mathrm{j} a}: \mathrm{n}^{6} \mathrm{j}_{\circ} \mathrm{a}: \mathrm{n}^{6} \quad$ 'Very messy' (e.g. a pile of books) ( $\mathrm{l}^{\mathrm{j} a: \mathrm{n}^{6}}$ is not attested as a monosyllabic adjective)

\section{Set 4.4 Voiced coronal obstruent onsets becomes another coronal obstruent}

Subset 4.4.1:

$[+$ voice $] \rightarrow[$-voice $]$

$[$-strid $] \rightarrow[+$ strid $]$

$[$-cont $] \rightarrow[+$ cont $]$

$P d \varepsilon: t^{7} s \varepsilon: t^{7} \quad$ 'Very quiet' 
Subset 4.4.2:

$[$-cont $] \rightarrow[+$ cont $]$

$[-$ lat $] \rightarrow[+$ lat $]$

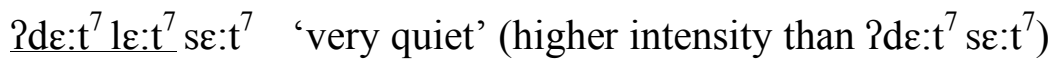

Set 4.5: Coronal obstruent becomes an obstruent with different place of articulation

Feature changes listed by subset below.

Subset 4.5.1:

$[$-cont $] \rightarrow[+$ cont $]$

[coronal $] \rightarrow[$ dorsal $]$

$\mathrm{t}_{\mathrm{C}} \mathrm{m}^{4} \mathrm{y}^{4} \mathrm{~m}^{4} \quad$ 'very fierce'

$6 ә \eta^{2} \mathrm{t}^{\mathrm{h}} \mathrm{u}^{3} \mathrm{\gamma u}^{4} \quad$ 'very stupid' ( $6 ә \eta^{2}$ 'stupid') ( $\mathrm{t}^{\mathrm{h}} \mathrm{u}^{3}$ is not attested as a monosyllabic adjective)

Subset 4.5.2:

$[+$ voice $] \rightarrow[$-voice $]$

[coronal] $\rightarrow[$ dorsal, +labial]

2da: $\eta^{1} \mathrm{k}^{\mathrm{w}} \mathrm{a}: \mathrm{\eta}^{2} \quad$ 'Very bright', esp. when light suddenly emerges (could be related Chinese guang 'light; ray; bright', but the Sui consultant views $\mathrm{k}^{\mathrm{w}} \mathrm{a}: \mathrm{\eta}^{2}$ as a purely Sui intensifier and it is not otherwise attested in Sui. However, a similar word $\mathrm{k}^{\mathrm{w}} \mathrm{a}: \mathrm{y}^{1}$ exists which means 'bright'.)

Subset 4.5.3:

$[+$ voice $] \rightarrow[$-voice $]$

[coronal $] \rightarrow[$ dorsal $]$

$[-$ nasal $] \rightarrow[+$ nasal $]$

tom $^{1} \underline{t o}^{2}$ yo $^{2} \mathrm{so}^{2}$ 'Very dull' (of a knife), 'very dumb' (of a person) (tom ' 'dull') (to ${ }^{2}$ is not attested as a monosyllabic adjective)

Subset 4.5.4:

$[$-cont $] \rightarrow[+$ cont $]$

[coronal $] \rightarrow[$ labial $]$

$\operatorname{tcon}^{3}$ fon $^{4} \quad$ 'very skinny' (higher intensity than $\operatorname{tcon}^{3} \operatorname{tccn}^{1}$ )

tiw $^{3}$ fiw $^{4} \quad$ 'very dried up' (higher intensity than tiw ${ }^{3} \mathrm{t}^{\mathrm{j}} \mathrm{j}^{5}$ ) 
Subset 4.5.5:

$[$-cont $] \rightarrow[+$ cont $]$

[coronal] $\rightarrow$ [labial]

$[+$ nasal $] \rightarrow[$-nasal $]$

?nəm ${ }^{1}$ fəm ${ }^{2}$ 'very black/dark'

Subset 4.5.6:

[-cont $] \rightarrow[+$ cont $]$

[coronal] $\rightarrow$ [labial]

[-voice $] \rightarrow[+$ voice $]$

ts $\varepsilon: k^{7} v \varepsilon: k^{7} \quad$ 'very bright'

Subset 4.5.7:

[-cont $] \rightarrow[+$ cont $]$

[coronal $] \rightarrow[$ labial $]$

$2 d^{j} a: n^{3} v^{j} a: n^{3} \quad$ 'very shiny/glittering'

Set 4.6: Tone change only

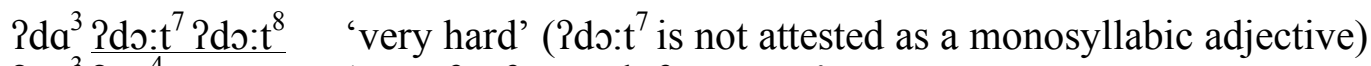

$\mathrm{Pna}^{3} \mathrm{Pna}^{4} \quad$ 'very far forward, frontmost'

$\mathrm{ti}^{3} \mathrm{ti}^{4} \quad$ 'very small' (same meaning as $\mathrm{ti}^{3} \mathrm{t}^{\mathrm{j}} \mathrm{u}^{4}$ )

$\operatorname{lon}^{2} l ə n^{6} l ə n^{3} \quad$ 'farthest behind' (only used when speaking to a child in a silly manner)

\section{Group 5. Fully reduplicated pairs}

The expressions in this set, primarily ABB full reduplication pairs, are considered distinct from the rhyming/alliterative intensifiers since (a) these $\mathrm{ABB}$ expressions are usually clearly onomatopoeic, unlike the rhyming/alliterative intensifiers and (b) these expressions usually occur as verb modifiers, unlike rhyming/alliterative intensifiers which apparently cannot modify verbs. (c) Further, note that the fully reduplicated pairs attach to phonologically distinct syllables (e.g., $\mathrm{ku}^{1}$ 'to laugh' $\rightarrow \mathrm{ku}^{1} \mathrm{Ci}^{5} \mathrm{Ci}^{5}$ 'to laugh quietly'). Although rhyming/alliterative intensifiers occasionally attach to a phonologically distinct adjective (e.g., $\mathrm{Pda}^{3}$ 'hard' $\rightarrow \mathrm{Pda}^{3} \mathrm{q \partial t}^{8} \mathrm{lat}^{8}$ 'very hard'), such examples are uncommon among the rhyming/alliterative type. Thus, the fully reduplicated set shown here appears to represent a separate process.

\begin{tabular}{|c|c|}
\hline $\operatorname{law}^{1} 10^{5} x \tilde{x}: t^{8} x \tilde{x}: t^{8}$ & 'sound of breathing' ( aw $^{1} 15^{5}$ 'to $i$ \\
\hline $2 n \varepsilon^{3} \mathrm{na}^{2} \mathrm{na}^{2}$ & 'sound of crying' (?pع 'cry') \\
\hline$\frac{{ }^{m} b^{j} a w^{3} b^{j} a w^{3}}{{ }^{n} d a^{1} y a: k^{7} y a: k}$ & $\begin{array}{l}\text { lling in sheets' (verb } \\
\text { ars falling' }\left({ }^{n} \mathrm{da}^{1} \text { 'ey }\right.\end{array}$ \\
\hline
\end{tabular}




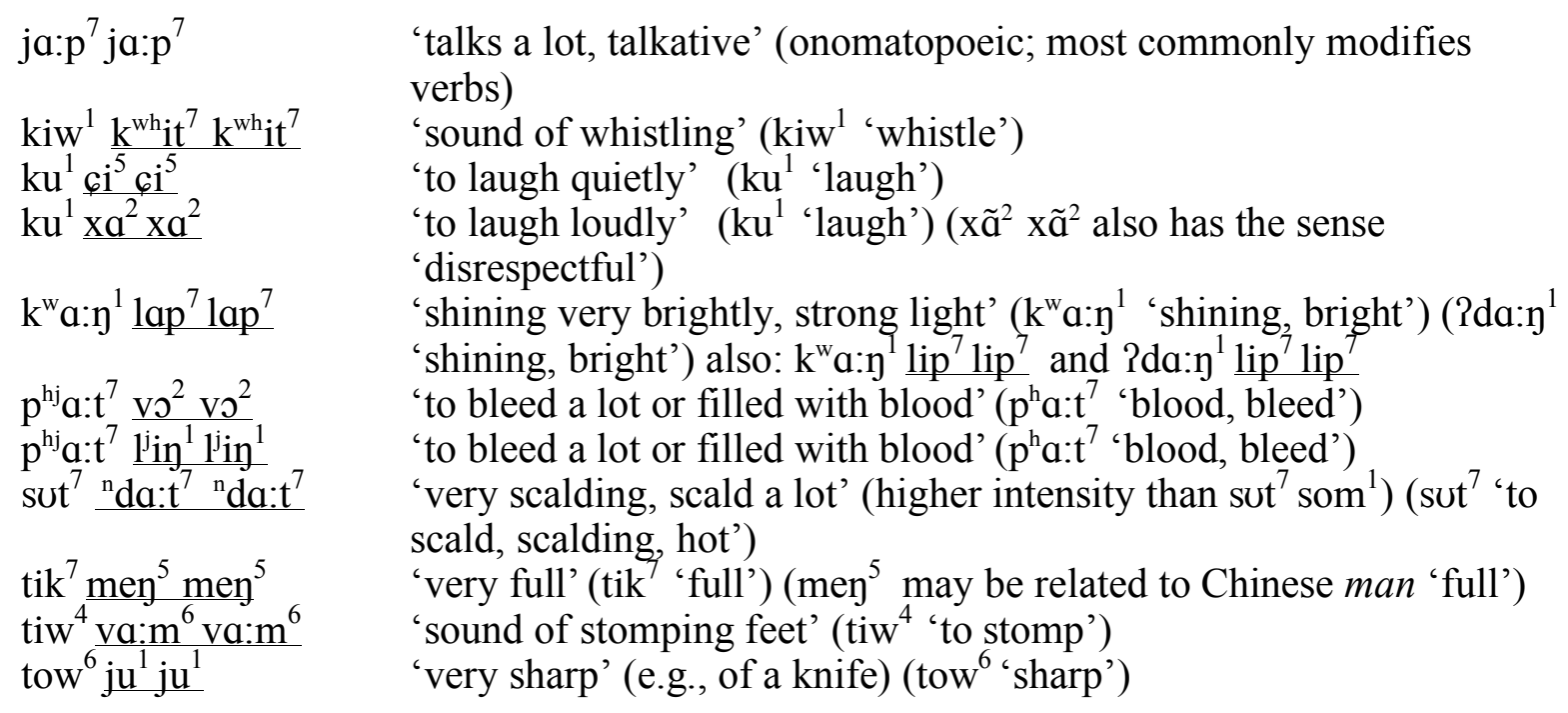

\section{Group 6. Three-syllable rhyming expressions}

In this section, the second and third syllable of three-syllable expressions are analyzed as base+reduplicant pairs. Neither of the syllables are attested as monosyllabic adjectives.

\section{Set 6.1: Coronal lateral to voiceless coronal nasal}

Features changed in this set:

[+voice] $\rightarrow[$-voice $]$

$[+$ lat $] \rightarrow[-$ lat $]$

$[+$ cont $] \rightarrow[$-cont $]$

$[$-nasal $] \rightarrow[+$ nasal $]$

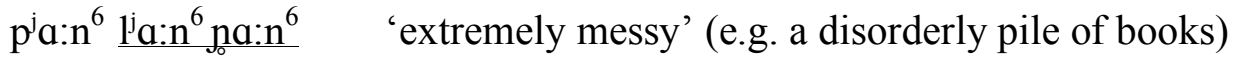

\section{Set 6.2: Coronal lateral to voiceless coronal stop}

Features changed in this set:

[+voice] $\rightarrow[$-voice $]$

$[+$ lat $] \rightarrow[-$ lat $]$

$[+$ cont $] \rightarrow[$-cont $]$

$[+$ son $] \rightarrow[-$-son $]$

$\operatorname{mow}^{1}{ }^{1}$ low $^{1}$ tow $^{2} \quad$ 'extremely crude/rash' (mow ${ }^{1}$ 'crude/rash')

qom $^{3} \frac{\operatorname{lom}^{2} \text { tom }^{2}}{5}$ 'sound of thunder' (onomatopoeia) (included here for comparison)

$\mathrm{qu}^{5} \underline{\mathrm{lu}^{5} \mathrm{tu}^{4}} \quad$ 'very round' (slightly different usage than $\mathrm{qu}^{5} 1 \mathrm{u}^{5} \mathrm{su}^{5}$; e.g. a person who has rolled into a ball; higher intensity than $\mathrm{qu}^{5} \mathrm{lu}^{5}$ ) 


\section{Set 6.3: Coronal lateral to voiceless coronal fricative}

Features changed:

[+voice] $\rightarrow[$-voice $]$

$[+$ lat $] \rightarrow[-$ lat $]$

$[$-strid $] \rightarrow[+$ strid $]$

$[+$ son $] \rightarrow[$-son $]$

$2 d a^{3} q \partial \eta^{5} l \partial \eta^{5} \operatorname{so\eta }^{5}$

'extremely hard' ( $\left(\mathrm{da}^{3}\right.$ 'hard')

$2 \mathrm{da}^{3} \mathrm{qat} \mathrm{t}^{8} 12 \mathrm{t}^{8} \mathrm{sat}^{8}$

'extremely hard' ( $\left(\mathrm{dd}^{3}\right.$ 'hard')

$2 \mathrm{da}^{3} \mathrm{qe}^{5} \frac{\mathrm{le}}{\mathrm{s}} \mathrm{se}^{5}$

Pd $\varepsilon: \mathrm{t}^{7} 1 \varepsilon: \mathrm{t}^{7} \mathrm{se}: \mathrm{t}^{7}$

$\varphi^{2} \eta^{2} \mathrm{tet}^{8} \mathrm{let}^{8} \mathrm{set}^{8}$

'extremely hard' ( $\mathrm{dda}^{3}$ 'hard')

'extremely quiet' ( $\mathrm{det}^{7}$ ' quiet')

'extremely stupid' ( $\mathrm{\sigma}^{2}{ }^{2}$ 'stupid')

mow ${ }^{1}$ low ${ }^{1}$ sow ${ }^{1}$

'extremely crude/rash' (mow 'crude/rash')

$\mathrm{pi}^{2} \mathrm{p}^{\mathrm{j}} \mathrm{u}^{1} \mathrm{l}^{\mathrm{j}} \mathrm{u}^{1} \mathrm{~s}^{\mathrm{j}} \mathrm{u}^{1}$

'extremely fat' ( $\mathrm{pi}^{2}$ ' $\mathrm{fat}$ ')

$\mathrm{pi}^{5} \underline{\mathrm{li}^{5}} \mathrm{si}^{5}$

'extremely messy', also includes the meaning 'narrow', e.g., a

messy, narrow room ( $\mathrm{pi}^{5} \mathrm{li}^{5}$ 'messy')

$p^{\mathrm{j} a j} j^{5} \underline{j}^{\mathrm{j} a j^{5}} s^{\mathrm{j}} \mathrm{aj} j^{5}$

$p^{\mathrm{j} a} \mathrm{a} \mathrm{n}^{6} \mathrm{l}^{\mathrm{j} a} \mathrm{a}: \mathrm{n}^{6} \mathrm{~s}^{\mathrm{j} a: n^{6}}$

'extremely messy', e.g., messy writing or messy soup, not the same meaning as $\mathrm{pi}^{5} \mathrm{li}^{5} \mathrm{si}^{5}$ or $\mathrm{p}^{\mathrm{j} a} \mathrm{a} \mathrm{n}^{6} \mathrm{l}^{\mathrm{j} a}: \mathrm{n}^{6} \mathrm{~s}^{\mathrm{j}} \mathrm{a}: \mathrm{n}^{6}$

$\mathrm{p}^{\mathrm{j}} \varepsilon: \mathrm{k}^{7} \mathrm{l}^{\mathrm{j} \varepsilon: \mathrm{k}^{7} \mathrm{~s}^{\mathrm{j}} \varepsilon: \mathrm{k}^{7}}$

'extremely messy' (e.g. a disorderly pile of books)

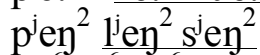

$\mathrm{qo}^{6} 10^{6} \mathrm{~s} \mathrm{~s}^{6}$

$\mathrm{qom}^{6} \mathrm{lom}^{6} \mathrm{som}^{6}$

$\mathrm{qak}^{7} \mathrm{lak}^{7} \mathrm{sak}^{7}$

'extremely dirty' ( $\mathrm{p}^{\mathrm{j}} \varepsilon: \mathrm{k}^{7}$ 'dirty')

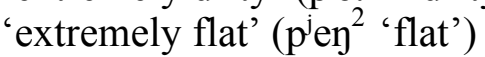

'extremely bald'

'extremely round' (qom ${ }^{6} \mathrm{lom}^{6}$ 'round')

'extremely mysterious' ( $\mathrm{qak}^{7} \mathrm{lak}^{7}$ 'mysterious')

$\mathrm{qok}^{8} \mathrm{lok}^{8} \mathrm{sok}^{8}$

$\mathrm{qu}^{5} 1 \mathrm{u}^{5} \mathrm{su}^{5}$

tca: $t^{7} \underline{1}^{\mathrm{j} a}: \mathrm{t}^{7} \mathrm{~s}^{\mathrm{j} a} \mathrm{a}: \mathrm{t}^{7}$

'very round-wheel-like' ( qok $^{8} \operatorname{lok}^{8}$ 'wheel'(n.))

'very round' (qu $1 \mathrm{u}^{5}$ 'round' (not wheels))

'very disorderly'

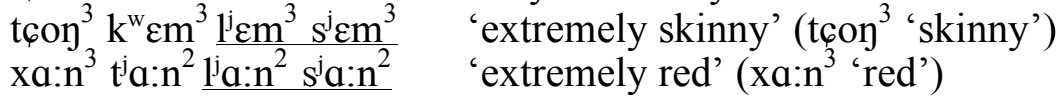

Set 6.4: Coronal nasal to voiceless coronal fricative

Subset 6.4.1:

Features changed in the onset:

$[+$ nasal $] \rightarrow[$-nasal $]$

$[+$ son $] \rightarrow[-$ son $]$

$[+$ voice $] \rightarrow[$-voice $]$

$[$-strid $] \rightarrow[+$ strid $]$

$[$-cont $] \rightarrow[+$ cont $]$

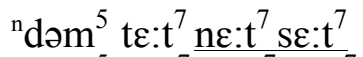

${ }^{n} d ə m^{5}$ tu: $t^{7} \underline{n v: t^{7} s v: t^{7}}$

${ }^{\mathrm{n}} \mathrm{dəm} \mathrm{m}^{5} \mathrm{te}^{2} \mathrm{ne}^{2} \mathrm{se}^{2}$

'extremely short (stature)' ( ${ }^{\mathrm{n}} \mathrm{dəm} \mathrm{m}^{5}$ 'short' (height))

'extremely short (stature)' ( ${ }^{\mathrm{n}} \mathrm{dəm}^{5}$ 'short'(height); note similarity with ${ }^{\mathrm{n}} \mathrm{d} \mathrm{m}^{5}$ t $\varepsilon: \mathrm{t}^{7} \underline{\left.n \varepsilon: \mathrm{t}^{7} \mathrm{~s} \varepsilon: \mathrm{t}^{7}\right)}$

'extremely short (stature)' ( ${ }^{\mathrm{n}} \mathrm{dəm}^{5}$ 'short' (height))

${ }^{n} \mathrm{~d}^{\mathrm{j}} \varepsilon \mathrm{m}^{3}$ to: $\mathrm{t}^{7}$ no: $\mathrm{t}^{7}$ so: $\mathrm{t}^{7}$

'extremely short (length)' ( ${ }^{\mathrm{n}} \mathrm{d}^{\mathrm{e}} \mathrm{en}^{3}$ 'short' (length)) 


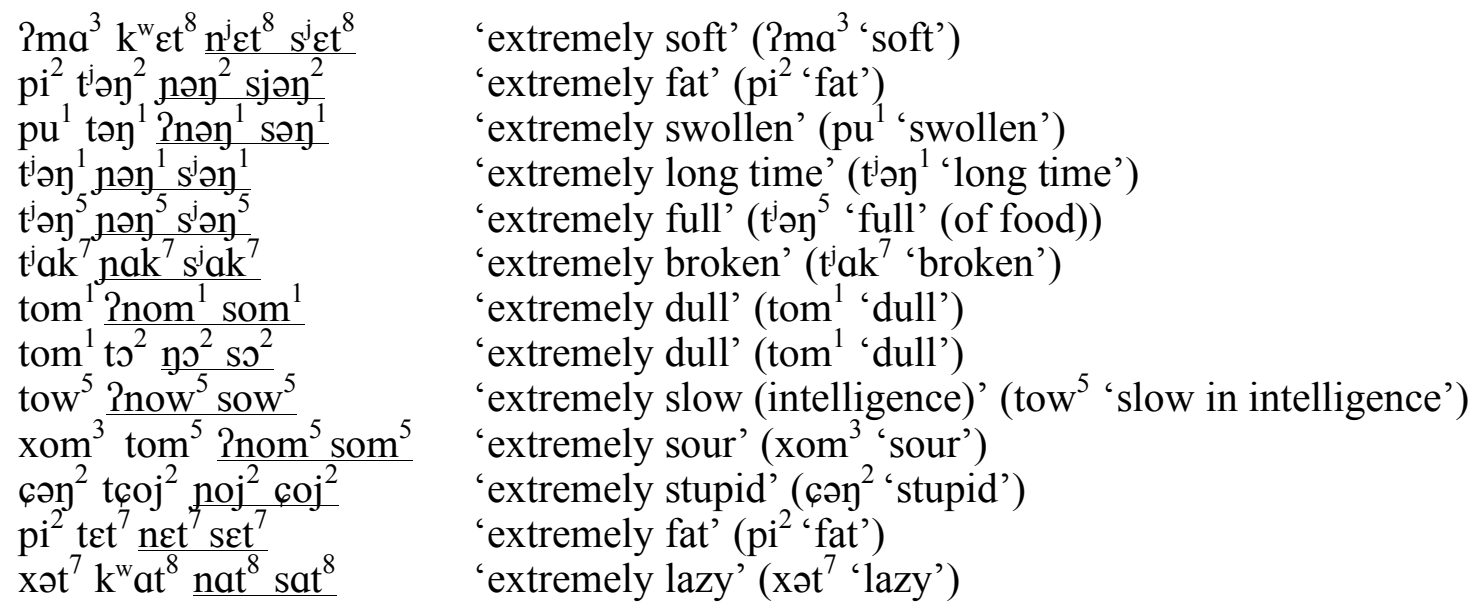

Subset 6.4.2:

Features changed in the onset:

$[+$ nasal $] \rightarrow[$-nasal $]$

$[+$ son $] \rightarrow[$-son $]$

[-strid $] \rightarrow[+$ strid $]$

$[$-cont $] \rightarrow[+$ cont $]$

Pyaj $^{3}$ naj $^{1} \mathrm{~s}^{\mathrm{j} a j^{1}} \quad$ 'extremely long (length)' ( $\mathrm{Pyaj}^{3}$ 'long' (length))

\section{Set 6.5: Voiced labial fricative to voiceless coronal fricative}

Features changed in this set:

[+voice $] \rightarrow[$-voice $]$

[labial $] \rightarrow$ [coronal $]$

ts $: \mathrm{k}^{7} \mathrm{v \varepsilon}: \mathrm{k}^{7} \mathrm{~s} \varepsilon: \mathrm{k}^{7} \quad$ 'extremely bright' (light)

$P d^{j} a: n^{3} v^{j} a: n^{3} s^{j} a: n^{3} \quad$ 'extremely shiny, glittery' ( $\left(d^{j} a: n^{3}\right.$ 'shiny, glittery')

\subsection{The No-Pattern Class}

Intensifiers in this class show no apparent phonological connection between base and reduplicant.

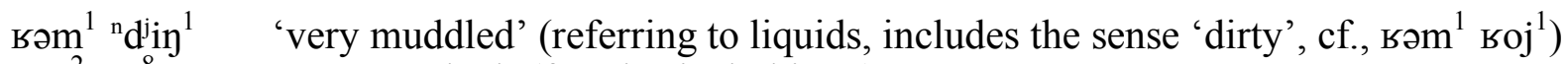
$\mathrm{qaj}^{2} \mathrm{pot}^{8} \quad$ 'very crooked' (for physical objects)

$\mathrm{qaj}^{2} \mathrm{jo}^{2} \quad$ 'very crooked' (esp. for describing a child or little animal in a humorous sense,

qaj $^{2}$ t $^{\mathrm{o}} \mathrm{k}^{8} \quad$ 'very crooked'

$\mathrm{nou}^{1}$ ?nak $^{7} \quad$ 'very smelly' (general use)

$\mathrm{pi}^{2}$ nəy $^{2} \quad$ 'very fat' (for both farm animals and people) 


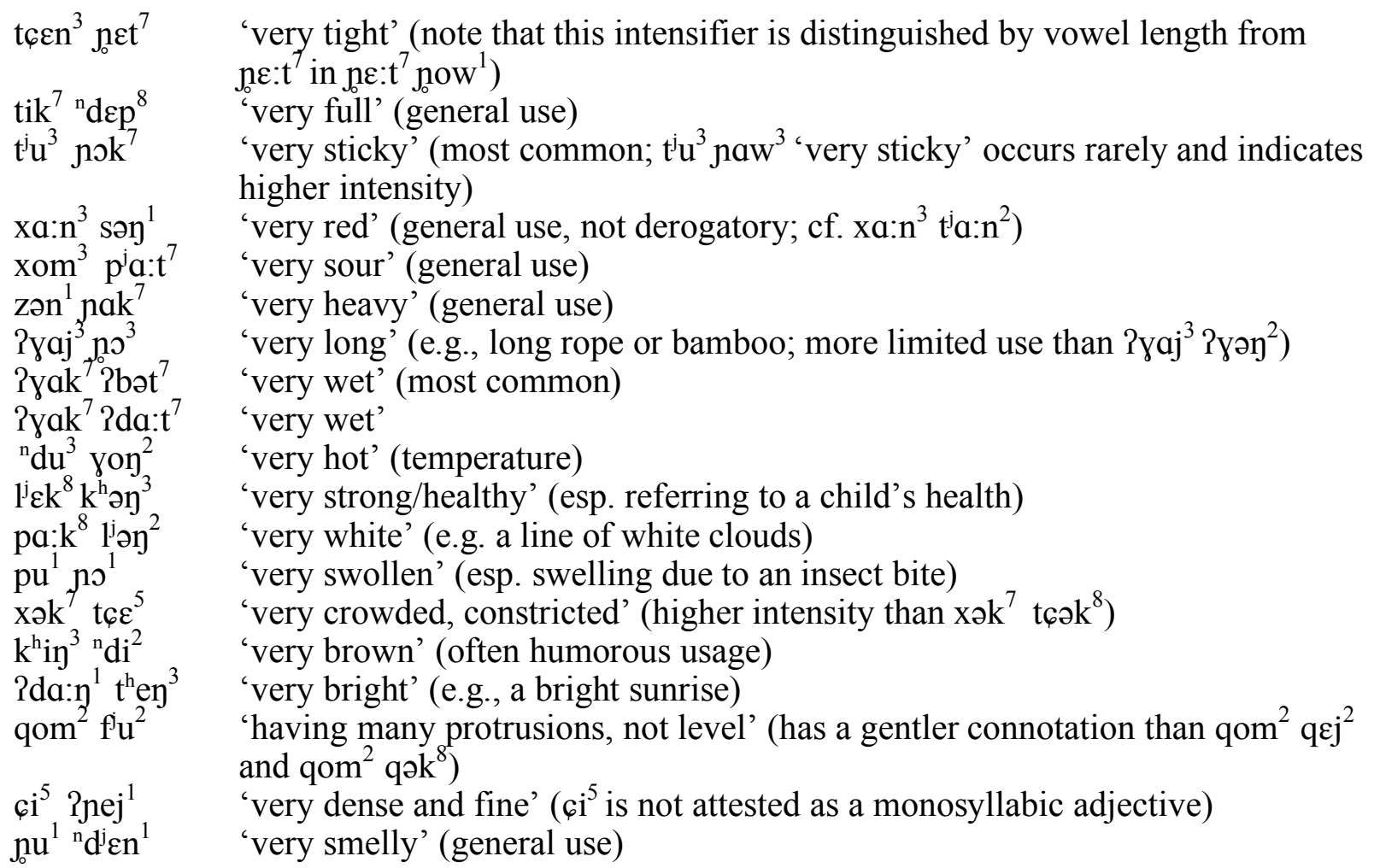

\section{References}

Burusphat, Somsonge, Xuechun Wei, and Jerold A. Edmondson. 2003. Sui (Shui)

Chinese-Thai Dictionary, Mahidol University, Bangkok (Sui, Chinese, and English entries by Wei and Edmondson).

Chao, Y.R. 1930. A System of Tone Letters. La Maitre phonetique 45/24-27.

Edmondson, Jerold A., John H. Esling, Jimmy G. Harris, and James Wei. 2004. A Phonetic Study of the Sui Consonants and Tones. Mon-Khmer Studies 34/47-66.

Edmondson, Jerold A. and David B. Solnit (eds.) 1988. Comparative Kadai: Linguistic studies beyond Tai. Dallas, TX: SIL.

He, Jiquan, Pan Chaofeng, and Liu Zhiyang. 1992. Shuizu minsu tanyou (Exploring folk customs of the Sui people). Chengdu, China: Sichuan Minorities Publishing.Kennard, Catherine Hicks. 2004. Copy But Don't Repeat: the Conflict of Dissimilation and Reduplication in the Tawala Durative. Phonology 21/3.303-323.

Li, Fang-Kuei. 1948. The Distribution of Initials and Tones in the Sui Language. Language 24/2.160-167.

Luo, Shiwu. 1992. Sandu Shuizu Zizhixian Zhi [Sandu Sui Autonomous County Report]. Guizhou, China: Guizhou People's Publishing.

McCarthy, John and Alan Prince. 1994. The Emergence of the Unmarked: Optimality in Prosodic Morphology. NELS 24, Proceedings of the 24th Conference of the Northeast Linguistics Society. University of Massachusetts, Amherst, 333-379.

Prince, Alan and Paul Smolensky. 1993. Optimality Theory: Constraint Interaction in Generative Grammar, Ms., Rutgers University \& University of Colorado, Boulder. Published 2004, Blackwell, Malden, Massachusetts and Oxford. 
Shuiyu Diaocha Baogao (Report on Investigations of the Sui Language). 1956. Ms.

Stanford, James N. 2007. Sui adjective reduplication as poetic morpho-phonology. Journal of East Asian Linguistics 16/2.87-111.

Thompson, Laurence C. 1965. A Vietnamese Grammar. Seattle: University of Washington Press. Wei, Xuechun. 1999. Shuiyu Xingrongci Houzhui Yanjiu [Research of Sui language adjective suffixes]. In Shuijiaxue Yanjiu Vol. 3. Guizhou, China: Guizhou Province Sui Association, 221-225.

Yip, Moira. 1995a. Identity Avoidance in Phonology and Morphology. Ms, University of California, Irvine.

Yip, Moira. 1995b. Repetition and its Avoidance: the Case of Javanese. In K. Suzuki and D. Elzinga (eds.), Proceedings of South Western Optimality Theory Workshop 1995 Arizona Phonology Conference Volume 5: University of Arizona Department of Linguistics Coyote Papers, 238-262.

Yip, Moira. 1996. Lexicon Optimization in Languages Without Alternations. In Jacques Durand and Bernard Laks (eds.) Current Trends in Phonology: Models and Methods, Vol. 2. Salford: University of Salford Publications, 757-788.

Yip, Moira. 1998. Identity Avoidance in Phonology and Morphology. In S. LaPointe, D. Brentari and P. Farrell (eds.) Morphology and its Relation to Phonology and Syntax. Stanford, CA: CSLI Publications, 216-246.

Yip, Moira. 1999. Reduplication as Alliteration and Rhyme. Glot International 4/8.1-7.

Yip, Moira. 2001. Segmental Unmarkedness Versus Input Preservation in Reduplication. In L. Lombardi (ed.), Segmental Phonology in Optimality Theory, Cambridge University Press, 206-230.

Yu Jiongbiao, Wil Snyder, and Donna Snyder. 1994. Two initial grammatical discoveries in the Fucun speech of Libo Buyi. In Stuart R. Milliken (ed.), SIL Occasional Papers on the Minority Languages of China vol. 1, Summer Institute of Linguistics, Hong Kong, 1-11.

Zeng, Xiaoyu and Yao Fuxiang. 1996. Hanshui Cidian [Chinese-Sui Dictionary]. Chengdu: Sichuan People's Publishing.

Zhang, Junru. 1980. Shuiyu Jianzhi [Sketch of the Sui language]. Beijing: Minorities Publishing House.

Author's contact information:

James Stanford

Rice University

Department of Linguistics

Herring Hall 217

(713)348-2956

E-mail: stanford@rice.edu 